\title{
"The effect of the european economic news releases to the US financial markets in the crisis period"
}

$\begin{array}{ll}\text { AUTHORS } & \text { Dimitrios Vortelinos } \\ \text { Konstantinos Gkillas }\end{array}$

Dimitrios Vortelinos and Konstantinos Gkillas (2016). The effect of the european ARTICLE INFO Investment Management and Financial Innovations, 13(4), 33-57. doi:10.21511/imfi.13(4).2016.04

DOI http://dx.doi.org/10.21511/imfi.13(4).2016.04

RELEASED ON Thursday, 15 December 2016

JOURNAL "Investment Management and Financial Innovations"

FOUNDER LLC "Consulting Publishing Company "Business Perspectives"

NUMBER OF REFERENCES

0

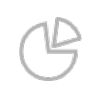

NUMBER OF FIGURES

0

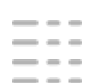

NUMBER OF TABLES

0

(C) The author(s) 2022. This publication is an open access article. 


\title{
Dimitrios Vortelinos (Greece), Konstantinos Gkillas (Greece)
}

\section{The effect of the European economic news releases to the US financial markets in the crisis period}

\begin{abstract}
This paper evaluates the effect of all European economic news releases on the US financial markets for the main crisis period from June 2007 up to October 2011. Evaluation concerns Sharpe ratios, as well as magnitude and frequency of volatility jumps for the periods before and after a news release. Sharpe ratios are examined with the risk of the excess returns being estimated by the flat-top Bartlett kernel estimator of Barndorff-Nielsen et al. (2008) with an optimal (in a finite sample) choice for the number of autocovariances, as suggested by Bandi and Russell (2011). Volatility jumps are detected according to the jump detection scheme of Ait-Sahalia and Jacod (2009).
\end{abstract}

Keywords:European economic news releases,crisis; macroeconomic variables, Sharpe ratio, jumps. JEL Classification: G01, G15.

\section{Introduction}

The economics and finance literature recognized that the financial crisis was a result of internationalized political issues (governmental interconnections, labor markets, globalization and slowing growth) combined with fiscal issues (leverage and risk-taking incentives of the financial sector, and the inability of financial regulation to cope with its opacity). A large part of such literature investigates the reasons and effects of the financial crises. Felices and Wieladek (2012) used a Bayesian dynamic common factor model to estimate the extent to which common factors underlie indicators of vulnerability to financial crises in both developing and developed countries. Another part concentrates on the reasons of the financial crises. Jagannathan et al. (2013) argued that the 2007 financial crisis was only an indication of the great recession of 2007-2009. Their analysis concentrates mostly on explaining the cause of the first acute symptom of the global imbalance (shock) between labor supply (from developed countries) and labor demand (to developing countries).

The short and long term linkages among the US and European stock markets have extensively been described and debated. There are a considerable number of research reports about the co-movements of these markets, particularly in times of financial instability and crises. Some recent papers such as Billio and Caporin (2010) found some evidence of contagion between Asian and American stock markets. Graham et al. (2012) examined the co-movement of European frontier stock markets with the USA and developed European markets. Ait-Sahalia et al. (2015) provided evidence of self-excitation and asymmetric

(c) Dimitrios Vortelinos, Konstantinos Gkillas, 2016.

Dimitrios Vortelinos, Lincoln International Business School, University of Lincoln, UK; Department of Business Administration, University of Patras, Greece.

Konstantinos Gkillas, Ph.D., Candidate Department of Business Administration, University of Patras, Greece. cross-excitation in the US and other international markets. In this framework, the impact of the economic announcements from the European to the US markets is interesting to research.

For this reason, literature includes several studies targeting at financial/economic announcements. Anderson (2010) investigated the stock market volatility reactions to announcements in the Euro Area markets and the USA before the 2007 financial crisis. Using intraday data of the US and Euro Area bond and stock markets, this paper found a strong upsurge in intraday volatility at the time of the release of the monetary policy decisions by the two central banks. Also, it was more pronounced for the US financial markets. Rosa (2011) examined the effects of the ECB announcements on US interest rates. Finnerty et al. (2013) examined the impact of credit ratings on 5-year credit default swap (CDS) spreads. Fiordelisi et al. (2014) researched the impact of monetary policy decisions of the interbank market on banks between June 2007 and June 2012. Ricci (2015) assessed the impact of ECB monetary policy announcements on the price of large European banks. Kenourgios et al. (2015) examined the effects of quantitative easing announcements by the European Central Bank, the Bank of Japan and the Bank of England on exchange rate dynamics.

Falagiardia and Rietz (2015) investigated the effects of ECB communications about unconventional monetary policy operations on the sovereign spreads of Greece, Ireland, Italy, Portugal and Spain relative to Germany between 2008 and 2012. More than fifty events concerning non-standard operations are identified and classified with respect to the specific ECB program. The empirical results suggest the ECB announcements for unconventional monetary policies substantially reduced long-term government bond yield spreads relative to German counterparts in all countries, except for Greece.

According to the corresponding literature, information arrivals affect financial markets. The US financial markets would be impacted by this 
volatility transmission both directly and indirectly. For example, a way to transfer the impact of economic announcements of the ECB to the US market is through the euro-US dollar exchange rate. There are several studies that support this argument. In some cases, the volatility actually increases on the back of the announcements. However, the global financial imbalance (or crisis) is attributable not only to any single event or news release (news releases for either macroeconomic variables' change or policy actions affecting macroeconomic variables), but also to a series of events or news releases. According to Bollerslev, Gibson and Zhou (2011), the estimated risk premium rises sharply during the two NBER dated macroeconomic recessions, as well as the periods of slow recovery and job growth after the 1991 and 2001 recessions. Almost all of the peaks in the series are readily identifiable with major macroeconomic or financial market developments. So, in terms of risk permium, the macroeconomic variables' changes are important. The impact of international macroeconomic announcements is analyzed for three euro exchange rates via highfrequency intraday data by Evans and Speight (2011).

The numerous news releases are categorized according to, firstly, the European economy's policy makers 1 and, secondly, the category of macroeconomic variables that each news release belongs to. According to the former categorization, the categories (policy makers) are: worldwide ${ }^{2}$, European Monetary Union, Germany, Italy, Spain, Portugal and Greece ${ }^{3}$. The macroeconomic categories are: liquidity \& balance, confidence indices, economic activity, consumption \& inflation, employment, and central banks.

The present paper evaluates European economic news releases on the following US financial markets: spot stock market, futures stock market, exchange traded funds, treasury bonds futures, and spot exchange rates for the main crisis period from June 2007 up to October 2011. The sampling frequency of the intraday data is 1 minute. The direct and indirect effect is examined via three evaluation criteria. The first evaluation criterion is

\footnotetext{
${ }^{1}$ News releases regarding the European economy may come from various sources that either determine or affect European economic policy. This is why they will be entitled as policy makers. The present paper concentrates only on either the most influential for European policy makers (e.g., European Monetary Union, World Bank, etc.), as well as the European countries mostly related to and affected by the crisis.

${ }^{2}$ The category of world wide concerns news releases that had to do with European economies from the following worldwide sources: World Economic Forum-Davos, G7 Meeting, OECD Economic Outlook, G8 Meeting, Jeddah Oil Meeting, G20 Meeting, IMF Meeting, Irish Stability Treaty Vote, and OPEC Meeting.

${ }^{3}$ This categorization is selected in order to signify the importance of each policy maker (European Monetary Union, worldwide entities, as well as European countries) that is more closely related to the financial crisis, in the US financial markets.
}

the ratio of the Sharpe ratios before and after each news releases ${ }^{4}$. The second and third criteria are associated to volatility jumps ${ }^{5}$. The second criterion is the ratio of the average magnitude values of daily jumps for the time periods before and after each news release. The third criterion is the ratio of the jump frequencies of daily jumps for the time periods before and after each news release.

To the best of our knowledge, this is the first paper to explore the impact of the ECB announcements on US financial markets during the financial crisis of 2008. We contribute to the literature on spillovers, volatility transmission and contagion across the most important US markets. Our paper aims to answer the following research questions. Firstly, which market is affected more by economic announcements? Secondly, which category of macro variables and which country affect more the US markets? Thirdly, which of the evaluation criteria are more hevily affected by the economic news releases? Fourthly, there may be domestic diversification's benefits from the European financial statements in US financial markets?

The rest of the paper is organized as follows. Section 1 reviews the volatility literature. Section 2 analytically describes data. Section 3 provides the methodology. Section 4 analyzes the empirical findings, and Section 6 offers concluding remarks.

\section{Literature review}

The various cases of volatility in stock markets are caused by multitude of unpredictable factors. Market regulation is unable to adapt to changes in technology and the weakness of freedom of information. Factors such as disruptions in the currency market, supplies, stocks and stock returns increase the uncertainty in the market. Speculators overreact to news and cause high volatility in the course of the shares. Also, volatility in stock markets appears to be caused by macro announcements, and particularly fiscal policy events from central banks. The investigation of the stock exchange unpredictability and macroeconomic factors' instability is impossible in confinement of the past work that had set up the rlationship between securities exchange costs unpredictability and some financial factors. Such certainties built up in the past which have a big effect on the present are

\footnotetext{
${ }^{4}$ The Sharpe ratio is based on the basic finance theory of the risk-return trade-off and market efficiency; see Sharpe (1994), among others. The Sharpe ratio (also known as the Sharpe index, the Sharpe measure, and the reward-to-variability ratio) measures the excess return (or risk premium) per unit of deviation in an investment asset or a trading strategy, typically referred to as risk (and is a deviation risk measure).

${ }^{5}$ Jumps are detected daily according to the detection scheme introduced by Ait-Sahalia and Jacod (2009).
} 
explored and displayed beneath. Below we report the main causes of volatility in stock markets as established in the research literature.

Numerous economic studies endeavored to seize the pregression of value returns utilizing various significant components (see Sharpe, 1964; Mossin, 1966; Fama and French, 1992; Gahart, 1997). Such variables incorporate CAPM beta, force, size, price, and profit yield. Fama (1970) has proposed that effective securities exchange developments are ordinarily a response to current news. Numerous experimental studies found that there are awry changes in the stock markets for a given occasion or stun prompts impressively higher instability in the stock returns. Speculators react more delicately to terrible news instead of uplifting news, which cause high unpredictability in the stock markets. Black (1976) explored that impact on unpredictability and discovered a solid negative connection between stock market changes and instability reaction are prone to be increased when stock costs decrease. The impact recommends that if there is a diminishing in stock cost of an organization, it lessens the estimation of value similar to obligation, and builts the money related influence. In this manner, it expands the danger of holding the values, which, thus, increase the future instability. In opposite, Schwert (1989) contends that influence alone can't impact awry unpredictability reaction.

Perotti (1995) proses that instability around an administration's dedication to its privatization program prevents speculators from taking an interest in the program, as an uncommited government is prone to turn around its arrangement after privatization incomes are raised. Minister and Veronesi (2012) demonstrate that such political instability drives up stock return unpredictability. Accordingly, a privatization program must be managed over a drawn out stretch of time to deliver a learning impact about the administration strategy's believability and, in this manner, determining political vulnerability (Pastor and Veronesi, 2012). Pan and Hsuech (1998) dissected the developments consequence and unpredictability. The outcome uncovered that there is an unidirectional overflow and a noteworthy slacked unpredictability. Schwarz (1998) demonstrated that stock unpredictability has been low and stable in these business sectors. Daly (1999) contends that the investigation of securities exchange instability has been developed as a huge point of enthusiasm for the economic literature on the grounds that the stock exchanges worldwide have turned out to be more incorporated and unstable generally. Park and Ratti (2002) investigated the dynamic interdependencies among genuine financial action, expansion, stock returns, and fiscal strategy. Wongbanpo and Sharma (2002) analyzed the relationship between the stock returns and five macroeconomic factors and found that in the long haul every one of the five stock value files were emphatically identified with development yield and had negative asociation with the total value level. Stiglitz (2002) states that rising capital record advancement has increased the instability of capital streams. Caner and Onder (2005) have outlined the factors that explain the sources of volatility in stock returns. Yields, exchange rates, interest rates, inflation rates and international market indices have been identified as the most significant variables to affect stock market volatility. Fama and French (2012) inspected the relative significance of size, price, and energy for stock returns in four key areas. Their discoveries affirm the huge logical force of return ebergy and price premiums in little top stocks. Different studies have additionally affirmed the hugeness of significant worth and energy in the US (see Fama and French, 1992; Jegadesh and Titman, 1993; Lee and Swaminathan, 2000). Baker and Haugen (2012) dissected twenty one developed and twelve developing business sector economies and reasoned that low-instability stocks beat their highunpredictability partners. Frot and Santiso (2012) assume that speculators don't incline toward political vulnerability about price dependability and future approaches in the political environment. AlZeaud and Al-Shbiel (2012) defined that there is a unidirectional instability of overflow impact when terrible news is unpredictably transmitted.

Boutchkova et al. (2012) comparatively demonstrate that high political instability around normal political occasions is connected to higher industry-level efficient and eccentric unpredictability examine proposes that political occesions that dimish the danger of an approach inversion (or arrangement change) ought to lessen stock return unpredictability. Diebold and Yilmaz (2012) inexact the unpredictability utilizing every day high and low costs, which is by all accounts an extremely boisterous and an off base instability intermediary. Panda and Deo (2014) discovered asymmetric instability overflow in all three periods. It was a higher asymmetry and instability overflow impact amid the post-emergency period, when contrasted with two different periods. Liow (2015) concentrated on portfolio enhancement and unpredictability anticipating by exploring the contigent instability and connection overflow among G7 nations. Do et al. (2016) think about intraday data transmission by exploring acknowledged overflows in higher minutes (instability, skewness and kurtosis) between the stock and trade markets. The scholastic research plots that the data obtained 
by managers and market members are distinctive and, to some degree, reciprocal.

Lim and Sek (2014) studied the relationship between transaction rate instability and stock return. They found that loan fee, cash supply, worldwide capitals, slacked conversion standard unpredictability and slacked stock returns instability influence stock returns instability in these nations. Lewal and Ijirshar (2015) likewise evaluated the relationship between transaction rate instability and bonds exchange execution and discover one-way causal connection from exchange rate unpredictability of the stock exchange in which expanded instability in the monetary market applies a negative impact on value advertise execution. Boehmer et al. (2014) found that the ascent of algorithmic exchanging at some time between 2001 and 2011 is related, by and large, with more liquidity, quicker value disclosure, as well as higher instability.

\section{Data description}

The sampling frequency of data is one (1) minute. Data start from June 1, 2007 and ends at October 14, 2011. Data were obtained from Pi trading base. Intraday data may reveal significant information about the US financial markets not easily seen on a daily basis, a significant number of researchers using intraday data in similar studies such as Kenourgios et al. (2015). Furthermore, the jump detection analysis requires smaller sample frequency from daily frequency (Andersen and Bollerslev, 1994; Andersen and Bollerslev, 1997).

For the entire sample period, the present paper examines the European news releases. The European economic news releases are grouped into two groups of categories. One group concerns the underlying policy maker and contains the following categories: world wide, European Monetary Union, Germany, Italy, Spain, Portugal and Greece. The latter group concerns the macro variables grouping to: liquidity \& balance, confidence indices, economic activity, consumption \& inflation, employment, and central banks. News releases are retrieved from the economic calendar of the Trading Economics data provider. For robustness purposes, the news releases are crosschecked with the economic calendar of the FX Street and official announcements from the ECB annual and monthly updated publications.

Analysis concerns data series from sixteen assets in four different US financial markets: (a) spot stock indices (Dow Jones Industrial Average, INDU; Nasdaq 100, NDX; S\&P 500, INX; Nasdaq composite, COMPX; Russell 2000, RUT; S\&P 100, OEX; S\&P 400 Midcap, IDX); (b) futures stock index (e-mini S\&P 500 continuous contract, ES; and e-mini Nasdaq 100 continuous contract, NQ); (c) exchange traded funds (Power Shares QQQ, QQQ; SPDR S\&P 500 growth ETF, SPY; SPDR Dow Jones Industrial Average ETF, DIA; SPDR S\&P Mid Cap 400 ETF, MDY; And, iShares Russell 2000 ETF, IWM); (d) US Treasury bond futures (30-year US Treasury yield, TYX); and (e) spot exchange rates (US dollar spot index, DXY). We examined the most important indices in different markets with specific geographical qualifier. The reason is based on the primary research question and that resulting differences in the reaction of markets consists a very important information for investors.

The data series for the US financial markets are depicted in Table1. Table 2 presents the categories of news releases (in two groupings) that are evaluated.

Table 1. List of data series

\begin{tabular}{|l|l|}
\hline \multicolumn{1}{|c|}{ Symbol } & \multicolumn{1}{|l|}{ Description } \\
\hline Panel A. Stock spot indices (US - SSI) & \multicolumn{1}{|l|}{} \\
\hline INDU & Dow Jones Industrial Average \\
\hline NDX & Nasdaq 100 Index \\
\hline INX & S \& P 500 Index \\
\hline COMPX & Nasdaq Compsite Index \\
\hline RUT & Russell 2000 Index \\
\hline OEX & S \& P 100 Index \\
\hline IDX & S \& P 400 Midcap Index \\
\hline Panel B. Stock index fectures (US -SIF) & E-Mini S \& P 500 Continuous Contract \\
\hline ES & E- Mini Nasdaq 100 Continuous Contract \\
\hline NQ & Power Sharea QQQ \\
\hline Panel C. Exchange traded funds (US- ETF) & SPDR S \& P 500 Growth ( US- ETF) \\
\hline QQQ & SPDR Dow Jones Industrial Average ETF \\
\hline SPY & SPDR S \& P MidCap 400 ETF \\
\hline DIA & iShares Russell 2000 Index Fund \\
\hline MDY & U.S Dollar Index \\
\hline IWM & \\
\hline Panel E. US dollar spot index (Us - SER) &
\end{tabular}

Notes: Table 1 reports all data series that are sampled every 1 minute. 
Table 2. List of groups of events and news releases

\begin{tabular}{|c|c|c|c|c|}
\hline Symbol & Categories & $\mathrm{N}$ & $\mathrm{n}$ & T \\
\hline \multicolumn{5}{|c|}{ Pabel A. Policy makers (PM) } \\
\hline WW & World wide events & 54 & 1.02 & 55 \\
\hline EMU & European Monetary Union & 784 & 2.45 & 1,915 \\
\hline $\mathrm{DE}$ & Germany & 641 & 2.15 & 1,377 \\
\hline IT & Italy & 59 & 2.36 & 139 \\
\hline ES & Spain & 49 & 1.57 & 77 \\
\hline PT & Portugal & 31 & 1.63 & 49 \\
\hline GR & Greece & 22 & 1.27 & 28 \\
\hline \multicolumn{5}{|c|}{ Panel B. Macroeconomic categories (Macro) } \\
\hline LB & Liquidity \& balance & 223 & 1.69 & 377 \\
\hline CIND & Confidence indices & 276 & 1.88 & 519 \\
\hline EA & Economic activity & 534 & 2.65 & 1,415 \\
\hline CINF & Consumption \& inflation & 310 & 2.58 & 800 \\
\hline EM & Employment & 114 & 1.78 & 203 \\
\hline $\mathrm{CB}$ & Central banks & 290 & 1.29 & 373 \\
\hline
\end{tabular}

Notes. Table 2 reports the categories of events and news releases (in two groups) are evaluated. Panel A concerns policy makers, whereas Panel B concerns macro variables. $\mathrm{N}$ is the total number of days with announcements for each category. $\mathrm{n}$ is the intradaily average number of announcements for each category, across all days. $T$ is the total number of announcements across the sample.

According to Table 2 and in the policy makers categorization, the European Monetary Union (EMU) with Germany close as second, has the highest total number of days with announcements for the corresponding announcement category $(\mathrm{N})$, the highest total number of dys with annoouncements for the corresponding announcement category (n), and the highest total number of announcements for an announcement category (T). The Southern European group of PIGS (Portugal, Italy, Grece and Spain), changing Ireland to Italy does not seem to be significant change in any of the three news releases indicators $(\mathrm{N}, \mathrm{n}$ and T). This group of EMU countries is really important for the ECB,with Germany as well because of its leading role.

Moreover, according to the macroeconomic categorization, the economic activity news releases (EA) with the consumption \& inflation category (CINF) second, has the highest total number of days with announcements for the corresponding announcement category $(\mathrm{N})$, the highest total number of days with announcements for the corresponding announcement category (n), and the highest total number of announcements for a category (T). The employment category of news releases (EM) seems to be the least significant across all.

\section{Methodology}

The response of US financial markets to European economic news releases is examined via the nonparametric estimator of realized volatility, squared jumps and Sharpe ratios evaluation and jumps evaluation. Following Ricci (2015), to avoid overlap and spurious results on economic announcements, we adopt the following criteria: 1) different announcements which belong to the same event-type category are quantified as a single event,. 2) when there is a decision to change the target interest rate, we consider it as the main event and, thus, we drop all the other events from the event study analysis.

We apply a simple t-test to evaluate the results of three measures. The null hypothesis $(\mathrm{H} 0)$ is that there is an equal mean between after and before the announcement; while, the alternative ( $\mathrm{Ha})$ is that the mean After is higher than the mean Before each announcement. Next, the realized volatility, jumps and Sharpe ratio measurements are deployed.

3.1. Volatility estimation. Realized volatility is the best non-parametric estimator of integrated volatility. Andersen, Bollerslev, Diebold and Labys (2001), ABDL, thereafter, introduced the prototype of realized volatility estimator, which simply is the sum of the observable intraday squared returns:

$R V_{t}^{(M)}=\sum_{t=1}^{M} r_{t, M}^{2}$

where $r_{t, M}$ is the intraday returns series.

The realized volatility estimator used was introduced by Bandi, Russell and Yang (2008). This estimator is symbolized as $R V_{B R, t}^{B N H L S(B a r)}$. It is the flat-top Bartlett kernel estimator of BarndorffNielsen et al. (2008) $\left(R V_{t}^{\text {BNHLS(Bar) }}\right)$ with an optimal (in a finite sample) choice for the number of autocovariances, as suggested by Bandi and Russell (2011). 


$$
\begin{aligned}
& R V_{t}^{\text {BNHLS(Bar) }} \stackrel{\text { def }}{=} R V_{i, \Delta, t}+ \\
& \left(\sum_{i=1}^{T / \Delta} r_{i, \Delta, t} \cdot r_{i-m, \Delta, t}+\sum_{i=1}^{T / \Delta} r_{i, \Delta, t} \cdot r_{i-m, \Delta, t}\right)
\end{aligned}
$$

where

$$
\operatorname{Min}\left(\operatorname{var}\left(\varphi^{B R}\right)\right)=\operatorname{Min}\left(\frac{Q}{T / \Delta} \cdot w \Omega_{1} w+4 \cdot\left(E\left(e^{2}\right)\right)^{2}\right.
$$

and

$$
w=\left(1,1, k\left(\frac{1}{\varphi(T / \Delta)}\right), \mathrm{K}, k\left(\frac{\varphi(T / \Delta)-1}{\varphi(T / \Delta)}\right)\right)
$$

The estimator used $\left(R V_{B R, t}^{B N H L S(B a r)}\right)$, is equal to $R V_{t}^{B N H L S(B a r)}$ with finite-sample number of autocovariances (q) chosen as $\varphi^{B R} M$ and $0<\varphi^{B R} \leq 1$ (where $\varphi^{B R}$ minimizes the finite sample MSE of the estimator), as well as $k(x)=1-x$ and $x=\frac{q-s}{q}$.

According to Bandi, Russell and Yang (2008), the following properties hold for the selected estimator. The finite sample criterion leads to a number of autocovariances which is larger on average (but less volatile) than the asymptotic criterion. The flt-top Bartlett kernel estimator should have no systematic biases and a smaller variance than their asymptotically optimal counterparts. Apart from this estimator's properties, it was also selected because it had the lowest ratio of average forecast error (i.e. variance forecast minus the 6-hour squared return) devided by the variance of the 6-hour returns among many realized volatility estimators analyzed by Bandi, Russell and Yang (2008). The average optimal (in the finite sample) number of autocovariances, and across all data series, is six (6).

3.2 Jump detection. The realized volatility estimator includes the contribution to the total variation stemming from the squared jump. This indicates the significance of jump to any realized volatility estimator. Ait-Sahalia and Jacod (2009) tried to figure out whether there is a significant difference between the realized quarticity of a specific sampling frequency and a multiple of it. The present paper employs the Ait-Sahalia and Jacod (2009) detection scheme.

The critical value for the test of this jump detection is

$$
\left.\left.F_{a}=2-\Phi_{a} \cdot V^{112} \cdot I\left(\left|R V_{B R, t}^{B N H L S(B a r)}\right|\right\rangle c_{1}\right) R V_{B R, t}^{B N H L S(B a r)}++I\left(\left|R V_{B R, t}^{B N H L S(B a r)}\right|\right\rangle c_{2}\right) R V_{B R, t}^{B N H L S(B a r)}
$$

where $c_{1}=0.95, c_{2}=0.05, R V_{B R, t}^{B N H L S(B a r)}$ is the realized volatility estimator used,

$$
V=\frac{160 \cdot(T / \Delta) \cdot\left(\frac{(T / \Delta)^{3}}{\pi^{-1 / 2} \cdot 16 \cdot \gamma(9 / 2)} \cdot \sum_{i=1}^{T / \Delta}\left|r_{i, \Delta, 1}\right|^{8} \cdot\left|r_{i, \Delta, 2}\right|\right)}{3 \cdot\left(\frac{(T / \Delta)}{\pi^{-1 / 2} \cdot 4 \cdot \gamma(5 / 2)} \cdot \sum_{i=1}^{T / \Delta}\left|r_{i, \Delta, 1}\right|^{4} \cdot\left|r_{i, \Delta, 2}\right|\right)^{2}}
$$$$
r_{i, \Delta, 1}=\ln \left(P_{c, 1}(i, \Delta)\right) / \ln \left(P_{c, 1}(i-1, \Delta)\right),
$$$$
r_{i, \Delta, 2}=\ln \left(P_{c, 2}(i, \Delta) / P_{c, 2}(i-1, \Delta)\right)
$$

$P_{c, 1}(i, \Delta)$ is the close prices for the specific sampling frequency, and iis the intraday close prices for the specific sampling frequency, and $P_{c, 2}(i, \Delta)$ is the intraday close prices for the multiple of the first sampling frequency (in $\left.P_{c, 1}(i, \Delta)\right)$. The standardized test statistic is

$$
S_{\text {test }}=\frac{S-2}{V^{1 / 2}}
$$

where

$$
S=\frac{\sum_{i=1}^{T / \Delta}\left|r_{i, \Delta, 1}\right|^{4}}{\sum_{i=1}^{T / \Delta}\left|r_{i, \Delta, 2}\right|^{4}}
$$

There are jumps for a day, when $S<F_{a}$. The empirical results reported below are relied on a significance level of $5 \%$.

$$
J M_{t}=\max \left(\left|R V_{B R, t}^{B N H L(B a r)}-V^{1 / 2}\right|, 0\right)
$$

The jump part $\left(J M_{t}\right)$ of the $R V_{B R, t}^{B N H L S(B a r)}$ estimator is estimated as in Andersen, Bollerslev, Frederiken and Nielsen $(2010)^{6}$. Jump frequency $\left(J F_{t}\right)$ is the frequency of occurence of daily jump within a number of days. So, it is the number of days that jumps are detected, and is expressed as a percentage

\footnotetext{
${ }^{6}$ The asymptotic properties for their jump detection scheme were provided by Barndorff-Nielsen and Shephard (2006), and Andersen, Bollerslev, Frederiksen and Nielsen (2010).
} 
of the total number of days for the examined (either before or after) time period. The indicator of the existence of at least one jump per daycan be depicted as: $B_{t}=I\left(J M_{t} \neq 0\right)$.

3.3. Sharpe ratio evaluation. The significance of the european economic news releases is evaluated via the ratio of the Sharpe ratios before and after each news release. The Sharpe ratio is not suggested for enrapturing the abnormal returns. However, comparing it (as erformance measure) before and after an economic event, it can signal a difference. The Sharpe ratio is a descriptive statistic. The Before time period is the days from the previous news release of this category of announcements up to the today's news release of the same category; and, the After time period is the days from today up to the next news release of the category. The Sharpe ratios are calculated ny estimating volatility with the $R V_{B R, t}^{B N H L S(B a r)}$ estimator. Because this volatility is estimated by a realized volatility estimator, the Sharpe ratio may be called realized Sharpe ratio. The daily realized Sharpe ratio is estimated as:

$$
R S R_{t}=\left|\frac{1}{T} \sum_{i=1}^{T} \frac{r_{i, t}-\bar{r}_{i, t}}{R V_{B R, t}^{B N H L S(B a r)}}\right|
$$

where $\mathrm{T}$ is the number of intraday observations in the estimation window (that is one-day as the realized skewness is daily), $R V_{B R, t}^{B N H L(B a r)}$ is the daily realized volatility estimator employed, $r_{i, t}$ is the intraday returns for day $t$ and intraday interval $i$, and $\bar{r}_{i, t}$ is the average of intraday returns on day $\mathrm{t}$. The ratio of the realized Sharpe ratios before and after each news release is estimated as:

$$
R_{R S R_{t}}=\frac{\operatorname{RSR}_{a, t}}{\operatorname{RSR}_{b, t}}=\frac{\frac{1}{T_{2}} \sum_{i=1}^{T_{2}} R S R_{i, t}}{\frac{1}{T_{1}} \sum_{i=1}^{T_{1}} R S R_{i, t}}
$$

The before realized Sharpe ratio $\left(R S R_{b, t}\right)$ is the average of the daily realized Sharpe ratios across the days $\left(T_{1}\right)$ starting from the previous news release of the specific category of announcements up to today's underlying news release, and the after realized Sharpe ratio $\left(R S R_{a, t}\right)$ is the average of the daily realized Sharpe ratios across the days $\left(T_{2}\right)$ starting from the underlying news release up to the next news release of the same category.

The effect of the news releases is examined daily and according to the Sharpe ratio criterion
$\left(R R S R_{t}\right)$, is answered by three measures. In specific, a news release is significant, when: (i) $R R S R_{t}>1$, (ii) $R R S R_{t}>$ average ratio across all assets for any specific news release day, and (iii) $R R S R_{t}>$ average ratio across all days with news release for the same category. After the daily evaluation of news releases, the effect of any category is depicted by the percentage of days for which any news release from the category is significant upon the total number of days with the category's news releases. These percentages are reported for the US financial markets in Tables 3-6 (see Appendix).

3.4. Jumps evaluation. The second evaluation of the effect of the European economic news releases is provided by two measures associated with volatility jump". The first such criterion is the ratio of average magnitude of daily jumps before and after each news release. It is estimated as

$$
R A J M_{t}=\frac{A J M_{a, t}}{A J M_{b, t}}=\frac{\frac{1}{T_{2}} \sum_{i=1}^{T_{2}} J M_{i, t}}{\frac{1}{T_{1}} \sum_{i=1}^{T_{1}} J M_{i, t}}
$$

The before average jump magnitude $\left(A J M_{b, t}\right)$ is the average of the daily magnitude of jumps across the days $\left(T_{1}\right)$ starting from the previous news release of the specific category of announcements up to today's underlying news release, and the after average jump magnitude $\left(A J M_{a, t}\right)$ is the average of the daily magnitude of jumps across the days $\left(T_{2}\right)$ starting from the underlying news release up to the next news release of the same category.

The effect of news releases on jumps is examined daily and, according to the first jump related criterion $\left(R A J M_{t}\right)$, is answered by three measures. In specific, a news release is significant, when: (i) $R A J M_{t}>1$, (ii) $R A J M_{t}>$ average ratio across all assets for any specific news release day, and (iii) $R A J M_{t}>$ average ratio across all days with news releases from the same category. After the daily evaluation of any group of news releases, the effect of a category is depicted by the percentage of days for which any news release from the category is significant upon the total number of days with the category's news releases. These percentages are reported for the US financial markets in Tables 7-10 (see in appendix).

\footnotetext{
${ }^{7}$ Jumps are detected according to the detection scheme introduced by Ait-Sahala and Jacod (2009).
} 
The second jump related evaluation criterion, symbolized as $R J F_{t}$, is the ratio of the jump frequencies of daily jumps before $\left(J F_{b, t}\right)$ and after $\left(J F_{a, t}\right)$ each news release. It is estimated as

$$
R J F_{t}=\frac{J F_{a, t}}{J F_{b, t}}=\frac{\sum_{i=1}^{T_{2}} B_{i, t}}{\sum_{i=1}^{T_{1}} B_{i, t}} .
$$

$R J F_{t}$ is the difference between the number of daily jump occurences in the period after $\left(J F_{a, t}\right)$ and the number of daily jump occurences in the period before $\left(J F_{b, t}\right)$. The jump frequency before a news release is the frequency of the daily occurences of jumps (as a percentage) across the days $\left(T_{1}\right)$ starting from the previous news release of the specific category up to today's underlying news release. The jump frequency after a news release is the frequency of the daily occurences of jump (as a percentage) across the days $\left(T_{2}\right)$ starting from the underlying news release up to the next news release of the same category. The occurence of at least one jump per day is indicated by $B_{i, t}$. This indicator takes the value of one (1) when there is at least one jump for the specific day $\mathrm{t}$ for a series of days either from $\mathrm{i}=1$ up to $T_{2}$ (the time period from the first day after the news release up to one day before the next news release from the same group) or from $\mathrm{i}=1$ up to $T_{1}$ (the time period from the first day after the previous news release from the same group of news release, up to a day before today's news release).

The effect is revealed daily and according to the second related criterion $\left(R J F_{t}\right)$, is answered by three measures. In specific, a news release is significant, when: (i) $R J F_{t}>1$, (ii) $R J F_{t}>$ average ratio across all assets for any specific news release day, and (iii) $R J F_{t}>$ average ratio across all days with news releases for the same category of news releases. After the daily evaluation of any group of news releases, the effect of a category is depicted by the percentage of days fo which any news release from the category is significant upon the total number of days of category's news releases. These percentages are reported for the US financial markets in Tables $11-14$ (see in appendix).

\section{Empirical findings}

4.1. Sharpe ratios. This sub-section analytically discusses the evaluation of the European news releases concerning the Sharpe ratio criterion. The corresponding results are presented in Tables 3-6. The highest Sharpe ratio evaluations do not vary across the three meaures used for this criterion. The average highest evaluation values are close to $48 \%$. This means that on average, $48 \%$ of the news leases are important.

The results for the US spot stock indices market (US-SSI) are presented in Table 3. Panel A indicates the Policy makers' categorization. According to this Panel and in a 5\% significance level, Nasdaq Composite index (COMPX) is more heavily affected. On the other hand, the S\&P 500 (INX) affected less than the other spot indices. The financial statements relating to the German economy (DE) and worldwide events (WW) have the most important news releases, while, the Greek economy announcements (GR) have the lowest. Germany accounts for a large share of the global GDP and has important export activities in the USA. Any crisis in the Euro Area impacts global GDP and is also transmitted indirectly in the US financial markets. Useful findings may arise for the investors and from the Panel B of Table 3. The category of confidence indices (CIND) has the most important impact, especially for the Dow Jones Industrial Average (INDU) and Nasdaq 100 (NDX) indices.

The findings are not differing substantially for the futures markets. Within the policy makers' categorization of Table 4 (panel A), the European Monetary Union (EMU) has the highest impact of news releases for both US stock futures indices (USSIF) and US spot exchange rate (US-SER) markets. While worldwide events (WW) affect both markets too. It should be noted that in spot market, the economic news of Greece (GR), firstly and Portugal (PT), secondly, have little or negligible impact. The futures markets indicate greater dependence on these two countries, while no statistically significant effect is apparent for the news from Spain (ES). For the US Treasury bond futures market (US-TBF), Germany (DE) is the most important category. Within the macro categorization of Table 4 (panel $\mathrm{B})$, both the US stock future indicex (US-SIF) and US Treasury bond futures (US-TBF) markets have most of important news releases for the central banks' (CB) category. For the US spot exchange rate (US-SER) market, the employment (EM) and confidence indices (CIND) news releases are most important.

Table 5 presents the results fo the US exchange traded funds market (US-ETF). The German economic news (DE) and world wide news (WW) are the most important. The Southern European countries with the greatest debt problems (Greece, 
first, and, then Portugal) did not affect this market. The confidence indices' news (CIND) and employment (EM) news have the most important news (panel B). The SPDR Dow Jones Industrial Average ETF (DIA) has most of the important news releases.

Finally, Table 6 reports the summarized results for the Sharpe ratio evaluations. The European Monetary Union (EMU) has the most important news releases, while Portugal (PT) has the least important in the policy makers' group of news releases (panel A). Interesting is the case of the Greek economy, which, although its effects are not at a low level, remained statistically significant at a 5\% level. The central banks' (CB) events have the heaviest impact in the macro categorization (panel B), across all US financial markets. From all US markets, the US spot exchange rate (US-SER) market was mostly affected by the European news releases.

4.2. Jump magnitude. The present sub-section concerns the European news releases' effect from a jump magnitude criterion. Results are reported in Tables 7-10 (see Appendix). The dispersion of evaluations around their central tendency is very low and lower than that of Sharpe ratio criterion. The central tendency of the effect jump magnitude evaluations is $40 \%$.

For the US spot stock indices (US-SSI) market (Table 7), the worldwide (WW) are the most important news releases. Portugal (PT) and Spain (ES) affecting most of the indices, while the news from the Greek economy (GR) are the least important. The S\&P 400 Midcap (IDX) has the most important news releases, while the Nasaq 100 (NDX) has the least. In panel B of Table 3, the confidence indice (CIND) has the most important impact.

Within the policy makers' categorization of Table 8 (panel A), Spain (ES) has the most important news releases for both the US stock futures (US-SIF) and US spot exchange rate (US-SER) market. For the US Treasury bond futures (US-TBF) market, Greece (GR) is the most important. Within the macro classification of Table 8 (panel B), the employment news (EM) are the most important for the US stock index futures (US-SIF); the confidence indices' news (CIND) are the most important for the US Treasury bond futures (US-TBF) market, and the liquidity \& balance (LB) news for the US spot exchange rate (US-SER) market.

Table 9 presents the results for the US exchange traded funds (US-ETF) market. For this market, the events of Portugal (PT) are the most important from Panel A, with the Grek (GR) and Spanish (ES) being the least. Within this market, the Power Shares QQQ index (QQQ) has the most important news releases, while iShares Russell 2000 index fund (IWM) has the least.

Table 10 depicts the summarized jump magnitude evaluations. Germany (DE) has the most important news releases from all policy makers; while, Greece (GR) has the least. The US Treasury bond futures (US-TBF) market is the market with the highest effect. The confidence indices (CIND) is the category of news releases whch is the most important from the macro categories. The US spot exchange rate (US-SER) market is the one that was mostly affected by the European economic news releases.

4.3. Jump frequency. The final sub-section of the empirical findings deals with the evaluation of the European economic news releases according to the jump frequency criterion. The corresponding results are presented in Tables 11-14. The dispersion of the evaluations around their average is low and in specific, lower than that of the Sharpe ratio criterion, but higher that that of the Sharpe ratio criterion. The average evaluation of news releases is 54\%; this is higher than the average evaluation of the news releases of the other two criteria. So, according to the jump frequency criteria, more than half the European news releases affect the US financial markets.

The results for the US spot stock index (US-SSI) market are presented in Table 11. According to the policy makers' categorization (panel A), the German news (DE) are the most important with the worldwide (WW) second. The Nasdaq composite index (COMPX) and the Russell 2000 (RUT) are mostly affected by news releases. From the macro classification, the EMU news are the most important.

For the US stock index futures (US-SIF) market (Table 12), the EMU had the most important news in the macro classification (panel A), while Grmany (DE) had the most important for the US spot exchange rate (US-SER) market, and Italy (IT) for the US Treasury bond futures (US-TBF) market. From the policy makers' classification (panel B), the liquidity \& balance (LB) is the most important group for the US stock index futures (US-SIF) market; the employment news (EM) is for the US Treasury bond futures (US-TBF) market; and the central banks (CB) news for the US spot exchange rate (US-SER) market.

Table 13 presents the results for the US exchange traded funds (US-ETF). World wide (WW) news has most of the important news from policy makers (panel A). The EMU and German (DE) had the most 
important news. The economic activity (EA) news releases are the most important from the macro classification (panel B). This is expected because of the trade relations between USA and European Union with Germany especially.

Table 14 depicts the summarized jump frequency evaluations. World wide (WW) events are the most important from the policy makers, followed by Germany (DE); While, Greece (GR) has the least important. Overall, few news releases are statistically significant, based on the jump frequency criterion. In almost all cases, the differences before and after the announcements are statistically significant. The confidence indices (CIND) are the most important news in the macro classification. Among all US markets, the US spot exchange rate (US-SER) market is more heavily affected.

\section{Concluding remarks}

Almost half of the European economic events are important across the US financial markets and the three evaluation criteria. Most of the events cause positive changes to the Sharpe ratios, jump magnitudes and jump frequencies for most of the US markets.

According to the policy makers categorization of Table 15, the category of news releases coming from the European Monetary Union (EMU) (and secondly, Germany (DE)) is the most important category. For the macro classification, the central banks (CB) (and secondly confidence indices, CIND) are the most important. All in all, the results from three criteria do not contrdict to one another; with a single exception for the US Treasury bond futures (US-TBF) market.

The economic news from the Southern European countries (Portugal, Italy, Grece and Spain) do not seem so important to the US financial markets. Only for the US Treasury bond futures (US-TBF) market, the EMU and German (DE) news are important. The degree of consistency of the results across markets and criteria is higher for the policy makers' rather than the macroeconomic classification.

\section{References}

1. Ait-Sahalia, Y.A. and Jacod, J. (2009). Testing for Jump in a Discretely Observed Process, Annals of Statistics, 37(1), pp. 184-222.

2. Ait-Sahalia, Y.A. and Jacod, J. (2011). Testing whether Jump have Finite or Infinite Activity, Annals of Statistics, 39(3), pp. 1689-1719.

3. Ait-Sahalia, Y.A., Mykland, P.A. and Zhang, L. (2011). Ultra High Frequency Volatility Estimation with Dependent Microstructure Noise, Journal of Econometrics, 160(1), pp. 160-175.

4. Ait-Sahalia, Y.A., Cacho-Diaz, J. And Laeven, R.J.A. (2015). Modeling Financial Contagion Using Mutually Exciting Jump Processes, Journal of Financial Economics, 117(3), pp. 585-606.

5. Ait-Sahalia, Y.A., Amengual, D. And Manresa, E. (2015). Market-based Estimation of Stochastic Volatility Models, Journal of Econometrics, 187, pp. 418-435.

6. Andersen, T.G., Bollerslev, T., Diebold, F.X. and Labys, P. (2001). The Distribution of Exchange Rate Volatility, Journal of the American Satistical Association, 96(453), pp. 42-55.

7. Andersen, T.G., Bollerslev, T., Diebold, F.X. and Labys, P. (2003). Modeling and Forecasting Realized Volatility, Econometrica, 71(2), pp. 579-625.

8. Andersen, T.G., Bollerslev, T., Frederiksen, P. And Arregaard Nielsen, M. (2010). Continuous-Time Models, Realized Volatilities, and Testable Distributional Implications for Daily Stock Returns, Journal of Applied Econometrics, 25(2), pp. 233-261.

9. Anderson, M. (2010). Using Intraday Data to Gauge Financial Market Response to Federal Reserve and ECB Monetary Policy Decision, International Journal of Central Banking, 6(2), pp. 107-116.

10. Bandi, F.M. and Russell, J.R. (2011). Market Microstructure Noise, Integrated Variance Estimators, and the Accuracy of Asymptotic Approximations, Journal of Econometrics, 160(1), pp. 145-159.

11. Bandi F.M., Russell, J.R. and Yang, C. (2008). Realized Volatility Forecasting and Option Pricing, Journal of Econometrics, 147(1), pp. 34-46.

12. Baker, N.I. and Haugen, R.A. (2012). Low Risk Stocks Outperform Within all Observable Markets of the World, Working paper, SSRN No. 2055431.

13. Barndorff-Nielsen, O., Hansen, P.R., Lunde, A. and Shephard, N. (2008). Designing Realized Kernels to Measure the Ex Post Variation of Equity Prices in the Presence of Noise, Econometrica, 76(6), pp. 1481-1536.

14. Barndorff-Nielsen, O. And Shephard, N. (2006). Econometrics of Testing for Jump in Financial Economics Using Bipower Variation, Journal of Financial Econometrics, 4(1), pp. 1-30.

15. Berger, A.N., Molyneux, P. and Wilson, J.O.S. (2012). The Oxford Handbook of Banking, Oxford: Oxford University Press.

16. Billio, M. And Caporin, M. (2010). Market Linkages, Variance Spillover and Correlation Stability: Empirical Evidences of Financial Contagion, Computational Statistics and Data Analysis, 54(11), pp. 2443-2458.

17. Black, F. (1976). Studies in Stock Price Volatility Changes, Proceedings of American Statistical Association, Business and Economics Statistics Section, pp. 177-181. 
18. Boehmer, E., Fong, K. And Wu, J. (2014). International Evidence on Algorithmic Trading, AFA 2013 San Diego Meetings Paper.

19. Bollerslev, T., Gibson, M. And Zhou, H. (2011). Dynamic Estimation of Volatility Risk Premia and Investor Risk Aversion from Option-Implied and Realized Volatilities, Journal of Econometrics, 160(1), pp. 235-245.

20. Boutchkova, M., Doshi, H., Durnev, A. and Molchanov, A. (2012). Precarious Politics and Return Volatility, Review of Financial Studies, 25(4), pp. 1111-1154.

21. Caner, S. And Onder, Z. (2005). Sources of Volatility in Stock Return in Emerging Market, Applied Economics, 37(8), pp. 929-942.

22. Cahart, M.M. (1997). On Persistence in Mutual Fund Performance, Journal of Finance, 52(1), pp. 57-82.

23. Curci, G. And Corsi, F. (2012). Discrete Sine Transform for Multi-Scale Realized Volatility Measures, Quantitative Finance, 12(2), pp. 263-279.

24. Daly, K. (1999). Financial Volatility and Real Economic Activity, England: Ashgate Publishing.

25. Diebold, F. And Yilmaz, K. (2012). Better to Give Than to Receive: Predictive Directional Measurement of Volatility Spillover, International Journal of Forecasting, 28(1), pp. 57-66.

26. Do, H.X., Brooks, R., Treepongkaruna, S. and Wu, E. (2016). Stock and Currency Market Linkages: New Evidence from Realized Spillovers in Higher Moments, International Review of Economics and Finance, 42, pp. 167-185.

27. Eling, M. (2012). What Do We Know About Market Discipline in Insurance?, Risk Management and Insurance Review, 15(2), pp. 185-223.

28. Evans, K.P. and Speight, A.E.H. (2011). Intraday Euro Exchange Rates and International Macroeconomic Announcements, European Journal of Finance, 17(2), pp. 83-110.

29. Falagiarda, M. And Reitz, S. (2015). Announcements of ECB Unconventional Programs: Implications for the Sovereign Spreads of Stressed Euro Area Countries, Journal of International Money and Finance, 53, pp. 276-295.

30. Fama, E. (1970). Efficient Capital Markets: A Review of Theory and Empirical Work, Journal of Finance, 25(2), pp. 383-417.

31. Fama, E. and French, K.R. (1992). The Cross-Section of Expected Stock Returns, Journal of Finance, 25(2), pp. 427-465.

32. Fama, E. and French, K.R. (1993). Common Risk Factors in the Returns on Stocks and Bonds, Journal of Financial Economics, 33(1), pp. 3-56.

33. Fama, E. and French, K.R. (2012). Size, Value, and Momentum in International Stock Returns, Journal of Financial Economics, 105(3), pp. 457-472.

34. Felices, G. and Wieladek, T. (2012). Are Emerging Market Indicators of Vulnerability to Financial Crises Decoupling from Globa Factors?, Journal of Banking and Finance, 36(2), pp. 321-331.

35. Finnerty, J.D., Miller, C.D. and Chen, R.R. (2013). The Impact of Credit Rating Announcements on Credit Default Swap Spreads, Journal of Banking and Finance, 37, pp. 2011-2030.

36. Fiordelisi, F., Galloppo, G. and Ricci, O. (2014). The Effect of Monetary Policy Interventions on Interbank Markets, Equity Indices and GSIFIs During Financial Crisis, Journal of Financial Stability, 11, pp. 49-61.

37. Flannery, M.J. (2012). Market Discipline in Bank Supervision, In: Berger, A.N., Molyneux, P. and Wilson, J.O.S. (eds.), The Oxford Handbook of Banking, Oxford: Oxford University Press.

38. Frot, E. and Santiso, J. (2012). Political Uncertainty and Portfolio Managers in Emerging Economies, Review of International Political Economy, 20(1), pp. 26-51.

39. Graham, M., Kiviaho, J. and Nikkinen, J. (2012). Integration of 22 Emerging Stock Markets: A ThreeDimensional Analysis, Global Finance Journal, 23(1), pp. 34-47.

40. Jagannathan, R., Kapoor, M. and Schaumburg, E. (2013). Why are we in a Recession? The Financial Crisis is the Symptom not the Disease!, NBER Working paper, No. 15404.

41. Jegadesh, N. and Titman, S. (1993). Returns to Buying Winners and Selling Losers: Implications for Stock Market Eficiency, Journal of Finance, 48(1), pp. 65-91.

42. Kenourgios, D., Papadamou, s. and Dimitriou, D. (2015). On Quantitative Easing and High Frequency Exchange Rate Dynamics, Research in International Business and Finance, 34, pp. 110-125.

43. Lawal, M. and Ijrshar, U.V. (2015). Empirical Analysis of Exchange Rate and Nigeria Stock Market Performance, International Journal of Science Research, 4(4), pp. 1592-1600.

44. Lee, C. and Swaminathan, B. (2000). Price Momentum and Trading Volume, Journal of Finance, 55(5), pp. 2017-2069.

45. Lim, S.Y. and Sek, S.K. (2014). Eploring the Inter-Relationship Between the Volatilities of Exchange Rate and Stock Return, Procedia Economics and Finance, 14, pp. 367-376.

46. Liow, K.H. (2015). Volatility Spillover Dynamics and Relationship across G7 Financial Markets, North American Journal of Economics and Finance, 33, pp. 328-365.

47. Mossin, J. (1966). Equilibrium in a Capital Asset Market, Econometrica: Journal of the Econometric Society, 34(4), pp. 768-783.

48. Olokoyo, F.O. and Ogunnaike, O.O. (2011). An Empirical Analysis of the Effect of Stock Market Crisis on Economic Growth: The Nigerian Case, Acta Uiversitatis Danubius, 7(4), pp. 172-186. 
49. Park, K. and Ratti, R.A. (2000). Real Activity, Inflation, Stock Returns, and Monetary Policy, Financial Review, 35(2), pp. 59-78.

50. Pastor, L. and Veronesi, P. (2012). Uncertainty about Government Policy and Stock Prices, Journal of Finance, 67, pp. 1219-1264.

51. Perotti, E.C. (1995). Credible Privatization, American Economic Review, 85(4), pp. 847-859.

52. Phillips, P.C.B. and Yu, J. (2009). A Two-Stage Realized Volatility Approach to Estimation of Diffusion Processes with Discrete Data, Journal of Econometrics, 150(2), pp. 139-150.

53. Protter, P. (1995). Stochastic Integration and Differential Equations. A New Approach, Springer.

54. Rosa, C. (2011). Words that Shake Traders. The Stock Market's Reaction to Central Bank Communication in Real Time, Journal of Empirical Finance, 18, pp. 915-934.

55. Ricci, O. (2015). The Impact of Monetary Policy Announcements on the Stock Price of Large European Banks During the Financial Crisis, Journal of Banking and Finance, 52, pp. 245-255.

56. Schwert, G.W. (1989). Why does Stock Market Volatility Change Over Time?, Journal of Finance, 44(5), pp. 1115-1153.

57. Sharpe, W.F. (1964). Capital Asset Prices: A Theory of Market Equilibrium Under Conditions of Risk, Journal of Finance, 19(3), pp. 425-442.

58. Sharpe, W.F. (1994). The Sharpe Ratio, Journal of Portfolio Management, 21, pp. 49-58.

59. Stiglitz, J.E. (2002). Capital Market Liberalisation and Exchange Rate Regimes: Risk Without Reward, Annals of the American Academy of Political and Social Science, 579(1), pp. 219-248.

60. Wongbanpo, P. and Sharma, S.C. (2002). Stock Market and Macroeconomic Fundamental Dynamic Interactions: ASEAN-5 countries, Journal of Asian Economics, 13(1), pp. 27-51.

61. Zhang, L., Mykland, P. and Ait-Sahalia, Y.A. (2005). A Tale of Two Time Scales: Determining Integrated Volatility with Noisy High-Frequency Data, Journal of the American Statistical Association, 100(472), pp. 1394-1411. 
Table 3. Sharpe ratio - US stock spot indices (US-SSI) market

\begin{tabular}{|c|c|c|c|c|c|c|c|c|c|c|c|c|c|c|c|c|c|c|c|c|c|c|c|c|}
\hline & \multicolumn{3}{|c|}{ INDU } & \multicolumn{3}{|c|}{ NDX } & \multicolumn{3}{|c|}{ INX } & \multicolumn{3}{|c|}{ COMPX } & \multicolumn{3}{|c|}{ RUT } & \multicolumn{3}{|c|}{ OEX } & \multicolumn{3}{|c|}{ IDX } & \multicolumn{3}{|c|}{ US-SSI } \\
\hline & \multicolumn{24}{|c|}{ Panel A. Policy makers (PM) } \\
\hline WW & 0.48 & $0.44^{*}$ & $0.74^{*}$ & $0.56^{*}$ & $0.54^{\star}$ & $0.78^{*}$ & 0.41 & $0.52^{*}$ & 0.26 & $0.44^{*}$ & 0.52 & $0.65^{*}$ & 0.46 & 0.48 & $0.13^{*}$ & $0.48^{\star}$ & $0.54^{\star}$ & $0.19^{\star}$ & 0.46 & $0.57^{\star}$ & $0.56^{*}$ & $0.47^{\star}$ & 0.52 & 0.47 \\
\hline EMU & $0.46^{*}$ & 0.47 & $0.53^{*}$ & 0.48 & $0.47^{\star}$ & $0.95^{*}$ & $0.45^{*}$ & 0.48 & 0.21 & 0.46 & $0.47^{*}$ & $0.94^{\star}$ & $0.46^{*}$ & $0.47^{\star}$ & 0.1 & $0.46^{*}$ & $0.48^{\star}$ & 0.06 & 0.47 & 0.46 & 0.36 & $0.46^{\star}$ & $0.47^{\star}$ & 0.45 \\
\hline $\mathrm{DE}$ & 0.42 & $0.53^{\star}$ & $0.72^{*}$ & 0.43 & $0.52^{\star}$ & $0.71^{\star}$ & 0.43 & 0.51 & 0.24 & $0.44^{*}$ & 0.52 & $0.76^{\star}$ & 0.41 & $0.50^{*}$ & $0.78^{\star}$ & $0.44^{\star}$ & $0.53^{*}$ & $0.83^{*}$ & 0.46 & $0.51^{\star}$ & $0.51^{*}$ & 0.43 & $0.52^{\star}$ & $0.65^{*}$ \\
\hline IT & 0.41 & 0.47 & $0.71^{\star}$ & 0.46 & $0.53^{*}$ & $0.15^{*}$ & 0.44 & $0.46^{*}$ & $0.90^{*}$ & $0.47^{*}$ & $0.53^{*}$ & $0.76^{\star}$ & 0.46 & $0.47^{\star}$ & $0.37^{\star}$ & 0.44 & 0.44 & $0.54^{*}$ & 0.44 & $0.53^{*}$ & 0.39 & 0.45 & $0.49^{*}$ & $0.55^{*}$ \\
\hline ES & 0.43 & $0.47^{\star}$ & $0.53^{*}$ & $0.47^{*}$ & 0.47 & 0.12 & 0.45 & 0.43 & $0.84^{*}$ & $0.51^{*}$ & 0.49 & $0.92^{*}$ & $0.49^{*}$ & $0.53^{*}$ & 0.45 & 0.45 & 0.37 & $0.80^{*}$ & 0.47 & $0.53^{*}$ & 0.27 & $0.47^{\star}$ & 0.47 & $0.56^{*}$ \\
\hline PT & 0.43 & $0.50^{*}$ & 0.4 & $0.47^{*}$ & 0.4 & $0.90^{*}$ & 0.43 & 0.47 & 0.07 & $0.50^{*}$ & $0.50^{*}$ & 0.5 & 0.4 & $0.50^{*}$ & 0.17 & 0.43 & $0.50^{*}$ & 0.18 & 0.37 & 0.5 & 0.2 & 0.43 & $0.48^{*}$ & 0.35 \\
\hline GR & 0.23 & 0.5 & 0.14 & 0.36 & 0.41 & 0.32 & 0.27 & $0.50^{\star}$ & 0.18 & 0.36 & 0.45 & 0.41 & 0.32 & 0.36 & 0.5 & 0.32 & $0.50^{*}$ & 0.18 & $0.33^{*}$ & 0.45 & 0.23 & 0.31 & $0.45^{*}$ & 0.28 \\
\hline \multirow[t]{2}{*}{ All-PM } & 0.41 & 0.48 & $0.54^{\star}$ & 0.46 & 0.48 & $0.56^{*}$ & 0.41 & 0.48 & 0.39 & 0.45 & $0.50^{*}$ & $0.71^{\star}$ & 0.43 & 0.47 & 0.36 & 0.43 & $0.48^{*}$ & 0.4 & 0.43 & $0.51^{*}$ & $0.36^{\star}$ & 0.43 & $0.49^{*}$ & 0.47 \\
\hline & \multicolumn{24}{|c|}{ Panel B. Macroeconomic variables (Macro) } \\
\hline LB & 0.46 & 0.46 & $0.89^{*}$ & 0.46 & $0.50^{*}$ & 0.32 & $0.47^{\star}$ & 0.43 & $0.52^{\star}$ & $0.48^{*}$ & 0.45 & $0.74^{*}$ & 0.47 & 0.44 & 0.02 & $0.47^{\star}$ & 0.48 & 0.04 & 0.47 & 0.42 & 0.35 & 0.47 & 0.45 & 0.41 \\
\hline CIND & $0.52^{*}$ & $0.48^{*}$ & $0.65^{*}$ & $0.51^{*}$ & $0.49^{*}$ & $0.59^{*}$ & $0.50^{*}$ & 0.47 & $0.29^{\star}$ & $0.49^{*}$ & 0.47 & $0.84^{\star}$ & 0.47 & 0.45 & $0.17^{\star}$ & 0.51 & 0.5 & $0.66^{\star}$ & 0.49 & $0.48^{\star}$ & 0.15 & $0.50^{\star}$ & 0.48 & 0.48 \\
\hline EA & 0.45 & $0.47^{\star}$ & $0.37^{\star}$ & 0.46 & 0.46 & $0.55^{*}$ & 0.47 & 0.45 & 0.14 & $0.48^{\star}$ & 0.46 & $0.54^{*}$ & 0.46 & 0.46 & 0.04 & 0.46 & 0.47 & 0.07 & 0.46 & 0.47 & $0.60^{*}$ & $0.46^{\star}$ & 0.46 & 0.33 \\
\hline CINF & 0.45 & 0.47 & $0.52^{\star}$ & 0.46 & $0.44^{\star}$ & 0.43 & 0.45 & 0.48 & $0.59^{\star}$ & $0.46^{*}$ & 0.45 & $0.79^{\star}$ & 0.47 & 0.5 & 0.03 & 0.45 & 0.49 & $0.33^{*}$ & $0.48^{\star}$ & 0.46 & $0.85^{\star}$ & 0.46 & 0.47 & $0.51^{\star}$ \\
\hline EM & $0.46^{*}$ & 0.37 & $0.82^{*}$ & 0.46 & 0.39 & 0.31 & 0.46 & 0.39 & 0.39 & 0.48 & 0.38 & $0.61^{*}$ & 0.46 & $0.51^{*}$ & 0.06 & 0.47 & 0.4 & $0.79^{*}$ & $0.47^{*}$ & 0.45 & 0.35 & 0.46 & $0.41^{*}$ & 0.48 \\
\hline $\mathrm{CB}$ & 0.45 & $0.48^{\star}$ & $0.75^{*}$ & 0.45 & 0.46 & 0.52 & 0.44 & 0.46 & $0.88^{\star}$ & 0.44 & $0.46^{*}$ & $0.57^{\star}$ & 0.44 & 0.43 & 0.04 & $0.44^{*}$ & 0.49 & $0.88^{\star}$ & 0.41 & $0.40^{*}$ & $0.71^{*}$ & 0.44 & 0.45 & 0.62 \\
\hline $\begin{array}{l}\text { All- } \\
\text { Macro }\end{array}$ & 0.47 & 0.46 & $0.67^{\star}$ & $0.47^{\star}$ & 0.46 & 0.45 & 0.47 & $0.45^{*}$ & 0.47 & 0.47 & 0.45 & $0.68^{\star}$ & 0.46 & 0.47 & 0.06 & $0.47^{\star}$ & $0.47^{\star}$ & 0.46 & 0.46 & 0.45 & $0.50^{\star}$ & $0.47^{\star}$ & 0.45 & 0.47 \\
\hline All-EE & 0.44 & $0.47^{\star}$ & $0.61^{\star}$ & 0.47 & 0.47 & $0.51^{*}$ & $0.44^{*}$ & 0.47 & 0.43 & 0.46 & $0.48^{*}$ & $0.70^{*}$ & 0.45 & 0.47 & 0.21 & $0.45^{\star}$ & $0.47^{\star}$ & 0.43 & 0.45 & 0.48 & $0.43^{\star}$ & 0.45 & 0.47 & 0.47 \\
\hline
\end{tabular}

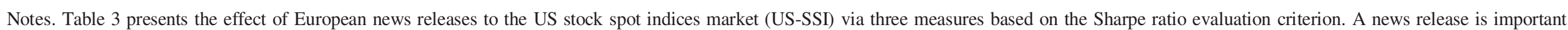

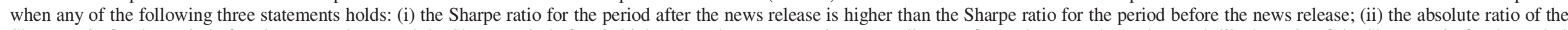

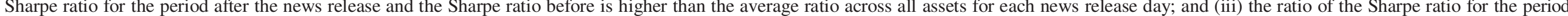

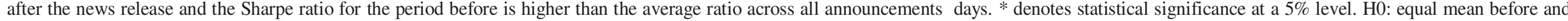
after, Ha: After>Before. 
Table 4. Sharpe ratio criterion - US stock index futures (US-SIF), US Treasury bond futures (US-TBF) and US spot exchange rates (US-SER) markets

\begin{tabular}{|c|c|c|c|c|c|c|c|c|c|c|c|c|}
\hline & \multicolumn{6}{|c|}{ US-SIF } & \multirow{2}{*}{\multicolumn{3}{|c|}{$\frac{\text { US-TBF }}{\text { TYX }}$}} & \multirow{2}{*}{\multicolumn{3}{|c|}{$\begin{array}{c}\text { US-SER } \\
\text { DXY }\end{array}$}} \\
\hline & \multicolumn{3}{|c|}{ ES } & \multicolumn{3}{|c|}{$\mathrm{NQ}$} & & & & & & \\
\hline & \multicolumn{12}{|c|}{ Panel A. Policy makers (PM) } \\
\hline WW & $0.52^{\star}$ & $0.57^{\star}$ & $0.11^{\star}$ & $0.46^{*}$ & $0.54^{\star}$ & $0.56^{\star}$ & $0.57^{\star}$ & $0.50^{*}$ & 0.13 & 0.46 & $0.59^{*}$ & 0.24 \\
\hline EMU & $0.55^{\star}$ & $0.64^{*}$ & 0.15 & $0.58^{*}$ & $0.60^{*}$ & 0.47 & $0.46^{*}$ & $0.47^{\star}$ & 0.22 & $0.56^{*}$ & $0.60^{*}$ & 0.42 \\
\hline $\mathrm{DE}$ & 0.47 & $0.55^{\star}$ & $0.60^{*}$ & 0.48 & $0.57^{\star}$ & $0.39^{*}$ & 0.38 & $0.49^{\star}$ & $0.78^{\star}$ & 0.44 & $0.52^{*}$ & 0.93 \\
\hline IT & 0.47 & 0.44 & 0.32 & 0.41 & 0.39 & 0.54 & 0.42 & 0.44 & 0.19 & 0.42 & 0.46 & 0.25 \\
\hline ES & 0.43 & 0.37 & 0.22 & 0.33 & 0.31 & 0.14 & $0.53^{*}$ & $0.41^{*}$ & $0.80^{\star}$ & 0.39 & $0.37^{*}$ & 0.96 \\
\hline PT & $0.53^{*}$ & $0.49^{*}$ & $0.57^{\star}$ & $0.47^{*}$ & $0.53^{*}$ & $0.53^{*}$ & 0.43 & $0.53^{*}$ & $0.63^{*}$ & 0.4 & 0.47 & 0.17 \\
\hline GR & $0.23^{*}$ & $0.59^{*}$ & 0.05 & 0.27 & 0.55 & 0.09 & 0.23 & 0.5 & 0.41 & 0.27 & 0.55 & 0.27 \\
\hline \multirow[t]{2}{*}{ All-PM } & 0.45 & 0.52 & 0.29 & 0.43 & 0.5 & 0.39 & 0.43 & 0.47 & 0.5 & 0.42 & 0.51 & 0.46 \\
\hline & \multicolumn{12}{|c|}{ Panel B. Macroeconomic variables (Macro) } \\
\hline LB & $0.54^{\star}$ & $0.55^{*}$ & 0.15 & $0.53^{*}$ & $0.54^{*}$ & $0.46^{*}$ & 0.46 & 0.48 & 0.09 & $0.52^{*}$ & $0.56^{*}$ & 0.44 \\
\hline CIND & 0.54 & $0.54^{*}$ & $0.25^{*}$ & $0.53^{*}$ & $0.53^{\star}$ & 0.35 & 0.47 & $0.46^{*}$ & $0.75^{\star}$ & $0.55^{*}$ & $0.58^{*}$ & 0.21 \\
\hline EA & 0.53 & $0.58^{\star}$ & 0.11 & 0.55 & $0.57^{\star}$ & 0.34 & 0.44 & 0.47 & 0.06 & $0.55^{*}$ & $0.59^{*}$ & 0.15 \\
\hline CINF & $0.53^{\star}$ & $0.58^{\star}$ & 0.18 & $0.60^{*}$ & $0.62^{\star}$ & $0.81^{*}$ & $0.45^{\star}$ & $0.45^{\star}$ & 0.26 & $0.59^{*}$ & $0.60^{*}$ & $0.87^{\prime}$ \\
\hline EM & $0.52^{\star}$ & $0.59^{\star}$ & 0.42 & $0.57^{*}$ & $0.62^{*}$ & $0.63^{*}$ & $0.40^{*}$ & $0.46^{*}$ & 0.32 & $0.63^{*}$ & $0.69^{*}$ & 0.25 \\
\hline $\mathrm{CB}$ & $0.57^{\star}$ & $0.64^{*}$ & 0.15 & $0.61^{*}$ & $0.63^{*}$ & 0.42 & $0.52^{*}$ & $0.52^{\star}$ & 0.52 & $0.57^{\star}$ & $0.63^{*}$ & 0.93 \\
\hline All-Macro & 0.54 & $0.58^{\star}$ & 0.21 & $0.56^{*}$ & $0.59^{\star}$ & 0.5 & 0.46 & $0.47^{\star}$ & 0.33 & 0.50 & $0.61^{*}$ & 0.48 \\
\hline All-EE & 0.5 & 0.55 & 0.25 & 0.5 & $0.55^{\star}$ & 0.45 & 0.45 & 0.47 & 0.42 & 0.50 & $0.56^{*}$ & 0.47 \\
\hline
\end{tabular}

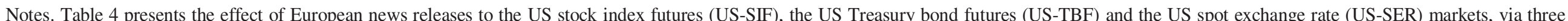

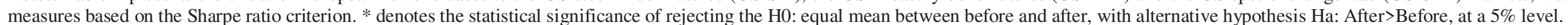


Table 5. Sharpe ratio - US exchange traded funds (US-ETF) market

\begin{tabular}{|c|c|c|c|c|c|c|c|c|c|c|c|c|c|c|c|c|c|c|}
\hline & \multicolumn{3}{|c|}{ QQQ } & \multicolumn{3}{|c|}{ SPY } & \multicolumn{3}{|c|}{ DIA } & \multicolumn{3}{|c|}{ MDY } & \multicolumn{3}{|c|}{ IWM } & \multicolumn{3}{|c|}{ US-ETF } \\
\hline & \multicolumn{18}{|c|}{ Panel A. Policy makers (PM) } \\
\hline WW & $0.52^{*}$ & $0.54^{\star}$ & $0.67^{\star}$ & 0.46 & $0.52^{\star}$ & $0.81^{*}$ & 0.44 & 0.41 & $0.93^{*}$ & 0.43 & $0.52^{*}$ & $0.70^{*}$ & 0.48 & $0.52^{*}$ & $0.50^{*}$ & 0.47 & $0.50^{*}$ & $0.72^{\star}$ \\
\hline EMU & 0.47 & $0.48^{\star}$ & $0.67^{*}$ & 0.47 & $0.48^{\star}$ & $0.98^{\star}$ & 0.48 & $0.48^{\star}$ & $0.86^{*}$ & $0.45^{*}$ & 0.45 & 0.4 & 0.45 & 0.48 & 0.43 & $0.46^{\star}$ & 0.47 & $0.67^{\star}$ \\
\hline DE & 0.42 & $0.50^{*}$ & $0.97^{*}$ & $0.45^{\star}$ & $0.54^{\star}$ & 0.41 & 0.44 & $0.52^{*}$ & $0.77^{\star}$ & 0.43 & $0.53^{*}$ & $0.73^{\star}$ & 0.42 & $0.49^{*}$ & $0.94^{*}$ & $0.43^{*}$ & 0.52 & $0.76^{*}$ \\
\hline IT & 0.47 & 0.47 & $0.76^{*}$ & 0.49 & 0.49 & $0.78^{*}$ & 0.42 & $0.51^{*}$ & $0.75^{\star}$ & 0.47 & $0.56^{*}$ & 0.42 & 0.44 & $0.53^{*}$ & $0.92^{*}$ & 0.46 & $0.51^{*}$ & $0.73^{\star}$ \\
\hline ES & 0.51 & 0.47 & $0.92^{*}$ & 0.49 & 0.47 & $0.76^{*}$ & $0.45^{\star}$ & 0.45 & $0.88^{\star}$ & 0.45 & 0.53 & 0.31 & 0.45 & $0.53^{*}$ & 0.31 & $0.47^{\star}$ & 0.49 & $0.64^{*}$ \\
\hline PT & 0.43 & 0.51 & 0.17 & 0.4 & 0.43 & 0.2 & $0.47^{\star}$ & 0.37 & 0.4 & 0.43 & $0.47^{*}$ & 0.07 & 0.47 & $0.53^{*}$ & 0.3 & 0.44 & $0.46^{*}$ & 0.23 \\
\hline GR & 0.32 & 0.36 & 0.36 & 0.27 & $0.50^{*}$ & 0.09 & 0.18 & $0.55^{*}$ & 0.27 & 0.36 & 0.36 & 0.23 & 0.32 & 0.32 & $0.64^{*}$ & 0.29 & 0.42 & 0.32 \\
\hline \multirow[t]{2}{*}{ All-PM } & 0.45 & $0.48^{\star}$ & $0.65^{*}$ & 0.43 & $0.49^{*}$ & 0.58 & 0.41 & 0.47 & $0.69^{*}$ & 0.43 & 0.49 & 0.41 & 0.43 & 0.49 & $0.58^{*}$ & 0.43 & 0.48 & $0.58^{*}$ \\
\hline & \multicolumn{18}{|c|}{ Panel B. Macroeconomic variables (Macro) } \\
\hline LB & 0.45 & 0.48 & 0.36 & 0.46 & $0.48^{\star}$ & 0.51 & 0.48 & $0.47^{*}$ & 0.57 & 0.44 & $0.44^{*}$ & 0.35 & 0.44 & 0.47 & 0.51 & 0.45 & 0.47 & 0.46 \\
\hline CIND & 0.49 & 0.47 & $0.72^{\star}$ & 0.49 & 0.49 & $0.97^{\star}$ & 0.51 & 0.48 & $0.59^{*}$ & 0.49 & 0.48 & 0.25 & 0.46 & 0.46 & 0.24 & 0.49 & 0.48 & $0.55^{\star}$ \\
\hline EA & 0.45 & 0.47 & $0.57^{\star}$ & 0.48 & 0.48 & $0.84^{*}$ & 0.46 & 0.47 & $0.79^{\star}$ & 0.43 & 0.45 & $0.57^{\star}$ & 0.44 & 0.46 & $0.89^{*}$ & 0.45 & 0.47 & $0.73^{\star}$ \\
\hline CINF & 0.45 & 0.45 & $0.81^{*}$ & $0.47^{\star}$ & 0.46 & $0.54^{*}$ & 0.45 & 0.45 & $0.86^{*}$ & 0.46 & 0.45 & $0.66^{*}$ & 0.44 & 0.46 & $0.84^{*}$ & 0.45 & 0.45 & $0.74^{*}$ \\
\hline EM & 0.44 & 0.41 & $0.56^{*}$ & 0.48 & 0.36 & 0.41 & $0.46^{\star}$ & 0.39 & $0.55^{\star}$ & $0.45^{*}$ & 0.4 & $0.58^{\star}$ & 0.45 & $0.49^{*}$ & 0.14 & $0.46^{\star}$ & 0.41 & 0.45 \\
\hline CB & 0.42 & 0.47 & $0.68^{*}$ & 0.42 & 0.43 & 0.4 & 0.46 & $0.48^{*}$ & $0.63^{*}$ & 0.42 & 0.4 & 0.41 & 0.39 & 0.43 & 0.33 & 0.42 & 0.44 & 0.49 \\
\hline All-Macro & 0.45 & $0.46^{\star}$ & $0.62^{*}$ & 0.47 & 0.45 & $0.61^{*}$ & 0.47 & 0.46 & $0.67^{*}$ & 0.45 & 0.44 & 0.47 & 0.44 & $0.46^{*}$ & 0.49 & 0.46 & 0.45 & 0.57 \\
\hline All-EE & 0.45 & $0.47^{\star}$ & $0.64^{*}$ & 0.45 & $0.47^{\star}$ & $0.60^{*}$ & 0.44 & 0.47 & $0.68^{\star}$ & 0.44 & 0.47 & $0.44^{*}$ & 0.44 & 0.48 & $0.54^{*}$ & 0.45 & 0.47 & $0.58^{\star}$ \\
\hline
\end{tabular}

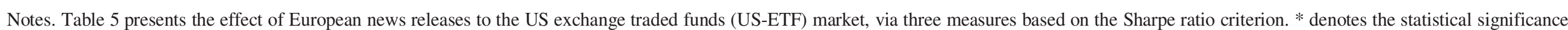
of rejecting the H0: equal mean between before and after, with alternative hypothesis Ha: After>Before, at a 5\% level. 
Table 6. Sharpe ratio criterion - Summarized results

\begin{tabular}{|c|c|c|c|c|c|c|c|c|c|c|c|c|c|c|c|c|c|c|}
\hline & \multicolumn{3}{|c|}{ US-SSI } & \multicolumn{3}{|c|}{ US-SIF } & \multicolumn{3}{|c|}{ US-TBF } & \multicolumn{3}{|c|}{ US-SER } & \multicolumn{3}{|c|}{ US-ETF } & \multicolumn{3}{|c|}{ US-markets } \\
\hline & \multicolumn{18}{|c|}{ Panel A. Policy makers (PM) } \\
\hline WW & 0.47 & $0.52^{*}$ & 0.47 & 0.49 & $0.56^{\star}$ & 0.34 & $0.57^{\star}$ & 0.5 & 0.13 & 0.46 & $0.59^{\star}$ & 0.24 & 0.47 & $0.50^{\star}$ & $0.72^{\star}$ & 0.49 & $0.52^{*}$ & 0.38 \\
\hline EMU & 0.46 & $0.47^{\star}$ & $0.45^{\star}$ & $0.57^{\star}$ & $0.60^{*}$ & $0.31^{\star}$ & 0.46 & 0.47 & 0.22 & $0.56^{*}$ & $0.60^{*}$ & 0.42 & 0.46 & 0.47 & $0.67^{*}$ & $0.50^{*}$ & $0.53^{*}$ & 0.41 \\
\hline $\mathrm{DE}$ & 0.43 & $0.52^{\star}$ & $0.65^{*}$ & 0.48 & $0.56^{*}$ & $0.50^{\star}$ & $0.36^{*}$ & 0.46 & $0.78^{*}$ & 0.44 & $0.52^{*}$ & $0.93^{*}$ & 0.43 & $0.52^{*}$ & $0.76^{*}$ & 0.43 & $0.52^{*}$ & $0.72^{*}$ \\
\hline IT & 0.45 & 0.49 & $0.55^{\star}$ & 0.44 & 0.42 & 0.43 & 0.42 & $0.44^{\star}$ & 0.19 & 0.42 & $0.46^{*}$ & 0.25 & 0.46 & $0.51^{*}$ & $0.73^{*}$ & 0.44 & 0.46 & 0.43 \\
\hline ES & 0.47 & $0.47^{\star}$ & $0.56^{\star}$ & 0.38 & 0.34 & 0.18 & $0.53^{*}$ & 0.41 & $0.80^{*}$ & 0.39 & 0.37 & $0.96^{*}$ & 0.47 & $0.49^{*}$ & $0.64^{*}$ & 0.45 & 0.42 & $0.63^{*}$ \\
\hline PT & 0.43 & 0.48 & 0.35 & 0.38 & 0.51 & 0.55 & 0.43 & 0.53 & 0.63 & 0.4 & 0.47 & 0.17 & 0.44 & 0.46 & $0.23^{*}$ & 0.42 & $0.49^{*}$ & 0.39 \\
\hline GR & $0.31^{*}$ & 0.45 & 0.28 & 0.25 & $0.60^{*}$ & 0.07 & 0.23 & 0.5 & 0.41 & 0.27 & $0.55^{\star}$ & 0.27 & 0.29 & 0.42 & $0.32^{*}$ & 0.27 & $0.50^{*}$ & 0.27 \\
\hline \multirow[t]{2}{*}{ All-PM } & 0.43 & 0.49 & 0.47 & 0.44 & $0.51^{*}$ & 0.34 & 0.43 & 0.47 & $0.50^{*}$ & 0.43 & $0.51^{\star}$ & 0.46 & 0.43 & $0.48^{\star}$ & $0.58^{*}$ & 0.43 & 0.49 & 0.47 \\
\hline & \multicolumn{18}{|c|}{ Panel B. Macroeconomic variables (Macro) } \\
\hline LB & 0.47 & 0.45 & 0.41 & $0.54^{*}$ & $0.55^{*}$ & 0.31 & $0.46^{*}$ & $0.48^{*}$ & 0.09 & $0.52^{*}$ & $0.56^{*}$ & 0.44 & $0.45^{\star}$ & 0.47 & 0.46 & $0.49^{*}$ & $0.50^{*}$ & 0.34 \\
\hline CIND & 0.5 & 0.48 & $0.48^{\star}$ & $0.54^{*}$ & 0.54 & 0.3 & $0.47^{*}$ & $0.46^{*}$ & $0.75^{*}$ & $0.55^{*}$ & $0.58^{\star}$ & 0.21 & 0.49 & 0.48 & $0.55^{\star}$ & 0.51 & $0.51^{*}$ & 0.46 \\
\hline EA & 0.46 & $0.46^{\star}$ & 0.33 & $0.54^{*}$ & $0.58^{*}$ & 0.23 & 0.44 & 0.47 & 0.06 & $0.55^{\star}$ & $0.59^{\star}$ & 0.15 & 0.45 & 0.47 & $0.73^{*}$ & 0.49 & 0.51 & $0.30^{*}$ \\
\hline CINF & 0.46 & $0.47^{\star}$ & 0.51 & $0.57^{\star}$ & $0.60^{*}$ & 0.5 & 0.45 & 0.45 & 0.26 & 0.59 & 0.6 & 0.87 & 0.45 & 0.45 & $0.74^{*}$ & 0.5 & $0.51^{*}$ & $0.57^{\star}$ \\
\hline EM & 0.46 & 0.41 & 0.48 & $0.55^{\star}$ & $0.61^{*}$ & 0.53 & 0.4 & 0.46 & 0.32 & $0.63^{\star}$ & $0.69^{\star}$ & 0.25 & 0.46 & $0.41^{\star}$ & 0.45 & $0.50^{*}$ & $0.52^{*}$ & $0.58^{\star}$ \\
\hline CB & 0.44 & 0.45 & 0.62 & 0.59 & $0.64^{*}$ & 0.29 & 0.52 & $0.52^{*}$ & 0.52 & $0.57^{\star}$ & $0.63^{*}$ & $0.93^{*}$ & 0.42 & $0.44^{*}$ & 0.49 & 0.51 & 0.54 & $0.58^{*}$ \\
\hline All-Macro & 0.47 & 0.45 & 0.47 & $0.56^{\star}$ & $0.59^{*}$ & 0.36 & 0.46 & $0.47^{\star}$ & 0.33 & 0.57 & $0.61^{*}$ & 0.48 & 0.46 & 0.45 & $0.57^{\star}$ & $0.50^{\star}$ & $0.51^{*}$ & 0.44 \\
\hline All-EE & 0.45 & 0.47 & 0.47 & $0.50^{\star}$ & $0.55^{\star}$ & 0.35 & 0.45 & 0.47 & 0.42 & 0.5 & $0.56^{\star}$ & 0.47 & 0.45 & $0.47^{*}$ & $0.58^{*}$ & 0.47 & $0.50^{*}$ & 0.46 \\
\hline
\end{tabular}

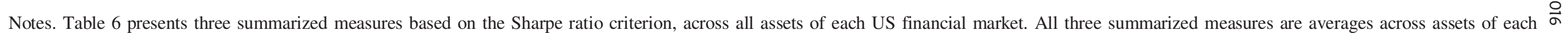
market. 
Table 7. Jump magnitude - US stock spot indices (US-SSI) market

\begin{tabular}{|c|c|c|c|c|c|c|c|c|c|c|c|c|c|c|c|c|c|c|c|c|c|c|c|c|}
\hline & \multicolumn{3}{|c|}{ INDU } & \multicolumn{3}{|c|}{ NDX } & \multicolumn{3}{|c|}{ INX } & \multicolumn{3}{|c|}{ COMPX } & \multicolumn{3}{|c|}{ RUT } & \multicolumn{3}{|c|}{ OEX } & \multicolumn{3}{|c|}{ IDX } & \multicolumn{3}{|c|}{ US-SSI } \\
\hline & \multicolumn{24}{|c|}{ Panel A. Policy makers (PM) } \\
\hline WW & 0.39 & $0.37^{\star}$ & 0.37 & 0.31 & 0.33 & 0.3 & $0.44^{*}$ & $0.44^{*}$ & 0.28 & 0.35 & 0.37 & 0.26 & 0.37 & 0.33 & $0.37^{\star}$ & 0.39 & $0.39^{*}$ & 0.26 & $0.52^{*}$ & 0.52 & 0.46 & $0.40^{*}$ & 0.39 & 0.33 \\
\hline EMU & 0.3 & 0.3 & $0.32^{*}$ & 0.32 & 0.32 & $0.33^{\star}$ & 0.34 & $0.36^{*}$ & $0.31^{*}$ & 0.34 & 0.34 & 0.33 & 0.4 & 0.42 & 0.35 & 0.32 & 0.33 & 0.31 & $0.36^{\star}$ & 0.36 & $0.32^{*}$ & $0.34^{*}$ & 0.35 & 0.32 \\
\hline $\mathrm{DE}$ & 0.33 & $0.31^{*}$ & 0.32 & $0.35^{*}$ & 0.32 & $0.34^{*}$ & $0.39^{*}$ & $0.40^{*}$ & $0.30^{*}$ & 0.36 & 0.36 & 0.33 & 0.41 & 0.39 & $0.35^{\star}$ & 0.36 & $0.38^{\star}$ & 0.32 & 0.4 & $0.37^{\star}$ & 0.34 & 0.37 & 0.36 & 0.33 \\
\hline IT & 0.32 & 0.37 & $0.32^{*}$ & 0.29 & 0.31 & $0.29^{*}$ & 0.37 & 0.44 & $0.29^{*}$ & 0.39 & 0.31 & 0.42 & 0.32 & 0.36 & 0.32 & $0.32^{*}$ & $0.44^{*}$ & 0.29 & $0.41^{*}$ & 0.41 & $0.34^{*}$ & 0.35 & 0.38 & 0.32 \\
\hline ES & 0.18 & $0.20^{*}$ & 0.27 & $0.18^{*}$ & $0.22^{*}$ & 0.22 & 0.33 & $0.31^{\star}$ & $0.31^{\star}$ & $0.29^{*}$ & 0.27 & 0.29 & 0.31 & $0.37^{\star}$ & $0.29^{*}$ & 0.29 & $0.20^{*}$ & 0.33 & $0.29^{*}$ & 0.39 & 0.29 & 0.27 & 0.28 & 0.29 \\
\hline PT & 0.23 & $0.27^{\star}$ & 0.23 & 0.37 & $0.40^{*}$ & $0.33^{\star}$ & $0.43^{*}$ & $0.30^{*}$ & 0.37 & $0.40^{*}$ & 0.43 & 0.43 & 0.33 & $0.40^{*}$ & $0.33^{*}$ & 0.5 & 0.37 & 0.33 & 0.43 & $0.43^{*}$ & 0.47 & 0.38 & $0.37^{\star}$ & 0.36 \\
\hline GR & $0.32^{*}$ & 0.36 & 0.36 & $0.27^{\star}$ & 0.27 & $0.32^{*}$ & 0.28 & $0.27^{\star}$ & $0.23^{*}$ & 0.27 & 0.18 & 0.36 & 0.23 & $0.27^{*}$ & 0.23 & 0.36 & $0.36^{*}$ & 0.27 & 0.27 & $0.27^{*}$ & 0.36 & 0.29 & 0.28 & 0.3 \\
\hline \multirow[t]{2}{*}{ All-PM } & $0.30^{*}$ & 0.31 & 0.31 & 0.3 & 0.31 & 0.3 & 0.37 & 0.36 & $0.30^{*}$ & 0.34 & 0.32 & 0.35 & 0.34 & 0.36 & $0.32^{*}$ & 0.36 & $0.35^{*}$ & 0.3 & 0.38 & 0.39 & 0.37 & 0.34 & $0.34^{*}$ & 0.32 \\
\hline & \multicolumn{24}{|c|}{ Panel B. Macroeconomic variables (Macro) } \\
\hline LB & 0.28 & 0.31 & $0.30^{*}$ & $0.33^{*}$ & $0.33^{\star}$ & 0.31 & $0.33^{\star}$ & 0.37 & 0.26 & $0.36^{*}$ & 0.38 & 0.29 & 0.46 & 0.44 & 0.32 & $0.30^{*}$ & 0.33 & 0.28 & $0.32^{\star}$ & $0.33^{*}$ & 0.32 & 0.34 & 0.36 & $0.30^{\star}$ \\
\hline CIND & 0.34 & $0.32^{*}$ & 0.33 & 0.34 & 0.34 & 0.33 & $0.32^{*}$ & $0.36^{\star}$ & 0.28 & $0.37^{\star}$ & 0.36 & 0.3 & 0.42 & $0.45^{*}$ & $0.33^{\star}$ & $0.33^{*}$ & $0.36^{*}$ & 0.3 & $0.38^{*}$ & 0.37 & $0.38^{\star}$ & $0.36^{*}$ & $0.37^{*}$ & 0.32 \\
\hline EA & 0.3 & 0.3 & $0.32^{*}$ & 0.28 & $0.29^{*}$ & 0.34 & 0.35 & $0.36^{*}$ & $0.32^{*}$ & 0.33 & 0.33 & 0.35 & 0.39 & $0.39^{*}$ & 0.37 & $0.31^{*}$ & 0.33 & 0.31 & $0.36^{*}$ & 0.36 & $0.37^{\star}$ & 0.33 & 0.34 & 0.34 \\
\hline CINF & $0.32^{*}$ & 0.31 & 0.32 & 0.31 & $0.31^{\star}$ & 0.34 & 0.35 & $0.35^{\star}$ & $0.34^{\star}$ & 0.38 & 0.35 & 0.36 & $0.41^{*}$ & $0.41^{\star}$ & 0.32 & 0.31 & $0.31^{\star}$ & 0.3 & $0.42^{*}$ & $0.39^{\star}$ & 0.32 & $0.36^{*}$ & 0.35 & 0.34 \\
\hline EM & 0.33 & 0.29 & $0.39^{*}$ & $0.32^{*}$ & 0.35 & 0.33 & 0.33 & 0.32 & 0.35 & 0.4 & 0.37 & 0.32 & 0.46 & 0.45 & $0.35^{\star}$ & $0.32^{\star}$ & 0.29 & $0.32^{*}$ & 0.38 & 0.34 & 0.35 & 0.36 & 0.34 & $0.33^{\star}$ \\
\hline $\mathrm{CB}$ & 0.27 & 0.3 & 0.27 & $0.29^{\star}$ & 0.32 & 0.33 & $0.29^{*}$ & $0.34^{\star}$ & $0.29^{*}$ & $0.33^{*}$ & 0.33 & 0.33 & 0.36 & $0.41^{*}$ & 0.38 & 0.32 & 0.33 & $0.31^{*}$ & $0.35^{*}$ & 0.37 & 0.33 & 0.32 & $0.34^{*}$ & 0.32 \\
\hline All-Macro & 0.31 & 0.31 & 0.32 & $0.31^{*}$ & 0.32 & 0.33 & $0.33^{*}$ & $0.35^{\star}$ & $0.31^{*}$ & $0.36^{*}$ & 0.35 & 0.33 & $0.42^{*}$ & 0.43 & $0.35^{\star}$ & 0.32 & $0.33^{*}$ & $0.30^{*}$ & $0.37^{*}$ & $0.36^{*}$ & 0.35 & 0.35 & 0.35 & 0.33 \\
\hline All-EE & 0.31 & 0.31 & $0.32^{*}$ & 0.31 & 0.32 & 0.32 & 0.35 & 0.36 & 0.31 & $0.35^{*}$ & 0.34 & 0.34 & 0.38 & $0.40^{*}$ & $0.34^{\star}$ & 0.34 & 0.34 & $0.30^{*}$ & 0.38 & $0.38^{*}$ & 0.36 & 0.35 & 0.35 & 0.33 \\
\hline
\end{tabular}

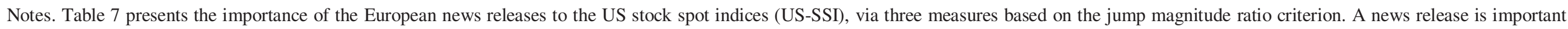

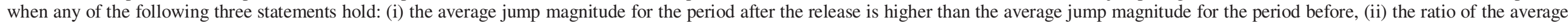

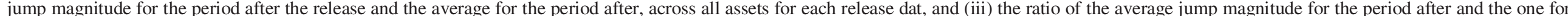

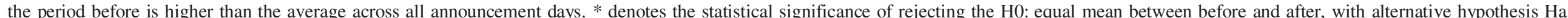
After $>$ Before, at a $5 \%$ level. 
Table 8. Jump magnitude criterion - US stock index futures (US-SIF), US Treasury bond futures (US-TBF) and US spot exchange rates (US-SER) markets

\begin{tabular}{|c|c|c|c|c|c|c|c|c|c|c|c|c|}
\hline & \multicolumn{6}{|c|}{ US-SIF } & \multirow{2}{*}{\multicolumn{3}{|c|}{$\begin{array}{c}\text { US-TBF } \\
\text { TYX }\end{array}$}} & \multirow{2}{*}{\multicolumn{3}{|c|}{$\frac{\text { US-SER }}{\text { DXY }}$}} \\
\hline & \multicolumn{3}{|c|}{ ES } & \multicolumn{3}{|c|}{ NQ } & & & & & & \\
\hline & \multicolumn{12}{|c|}{ Panel A. Policy makers (PM) } \\
\hline WW & 0.31 & 0.35 & $0.31^{*}$ & 0.26 & 0.30 & 0.24 & 0.35 & $0.44^{*}$ & 0.37 & $0.33^{*}$ & 0.44 & 0.33 \\
\hline EMU & 0.40 & $0.49^{*}$ & 0.25 & 0.41 & $0.45^{*}$ & 0.21 & $0.42^{*}$ & $0.47^{\star}$ & 0.30 & $0.41^{*}$ & $0.51^{*}$ & 0.32 \\
\hline $\mathrm{DE}$ & 0.44 & $0.46^{\star}$ & 0.36 & $0.42^{*}$ & 0.41 & 0.22 & 0.45 & $0.50^{*}$ & 0.25 & $0.51^{*}$ & $0.48^{*}$ & 0.34 \\
\hline IT & 0.42 & $0.53^{*}$ & $0.34^{*}$ & 0.44 & $0.54^{*}$ & 0.34 & $0.47^{*}$ & $0.51^{*}$ & 0.39 & 0.44 & $0.53^{*}$ & 0.41 \\
\hline ES & $0.51^{*}$ & $0.61^{*}$ & 0.22 & $0.51^{*}$ & $0.59^{\star}$ & 0.22 & 0.39 & 0.39 & 0.29 & $0.53^{*}$ & $0.65^{*}$ & 0.33 \\
\hline PT & 0.37 & 0.37 & 0.27 & 0.37 & 0.37 & 0.30 & 0.39 & 0.33 & 0.17 & 0.47 & 0.40 & 0.27 \\
\hline GR & 0.36 & $0.59^{*}$ & 0.27 & 0.41 & $0.54^{\star}$ & 0.36 & $0.59^{*}$ & 0.55 & 0.32 & 0.50 & 0.50 & 0.36 \\
\hline \multirow[t]{2}{*}{ All-PM } & 0.40 & 0.49 & $0.29^{*}$ & 0.40 & $0.46^{\star}$ & 0.27 & 0.44 & 0.46 & 0.30 & $0.46^{*}$ & 0.50 & 0.34 \\
\hline & \multicolumn{12}{|c|}{ Panel B. Macroeconomic variables (Macro) } \\
\hline LB & 0.43 & 0.45 & 0.31 & $0.41^{*}$ & 0.49 & 0.22 & 0.39 & $0.45^{*}$ & 0.31 & 0.49 & $0.51^{*}$ & 0.42 \\
\hline CIND & 0.42 & 0.48 & 0.33 & $0.44^{*}$ & $0.44^{*}$ & 0.28 & $0.46^{*}$ & $0.48^{\star}$ & 0.31 & 0.42 & 0.48 & 0.38 \\
\hline EA & 0.39 & $0.51^{*}$ & 0.22 & 0.40 & 0.45 & 0.19 & 0.40 & $0.48^{*}$ & 0.31 & 0.42 & $0.52^{*}$ & 0.36 \\
\hline CINF & 0.40 & $0.47^{\star}$ & 0.21 & 0.39 & $0.44^{\star}$ & 0.15 & 0.45 & $0.47^{\star}$ & 0.31 & 0.42 & $0.49^{*}$ & 0.34 \\
\hline EM & 0.43 & $0.53^{*}$ & 0.36 & 0.45 & $0.54^{*}$ & 0.17 & 0.38 & 0.46 & 0.23 & 0.43 & $0.54^{*}$ & 0.27 \\
\hline $\mathrm{CB}$ & $0.40^{*}$ & $0.50^{*}$ & 0.28 & 0.41 & $0.43^{*}$ & 0.30 & 0.42 & 0.48 & 0.30 & 0.36 & $0.52^{\star}$ & 0.26 \\
\hline All-Macro & 0.41 & 0.49 & 0.29 & 0.42 & $0.47^{*}$ & 0.22 & 0.42 & $0.47^{\star}$ & 0.29 & $0.42^{*}$ & $0.51^{*}$ & 0.34 \\
\hline All-EE & 0.41 & $0.49^{*}$ & $0.29^{*}$ & $0.41^{*}$ & 0.47 & 0.25 & 0.43 & $0.47^{\star}$ & 0.30 & $0.44^{*}$ & $0.51^{*}$ & 0.34 \\
\hline
\end{tabular}

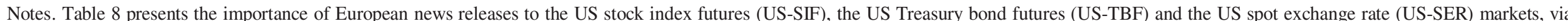

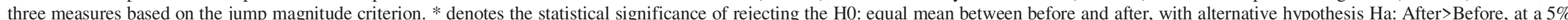
level. 
Table 9. Jump magnitude criterion - US exchange traded funds (US-ETF) market

\begin{tabular}{|c|c|c|c|c|c|c|c|c|c|c|c|c|c|c|c|c|c|c|}
\hline & \multicolumn{3}{|c|}{ QQQ } & \multicolumn{3}{|c|}{ SPY } & \multicolumn{3}{|c|}{ DIA } & \multicolumn{3}{|c|}{ MDY } & \multicolumn{3}{|c|}{ IWM } & \multicolumn{3}{|c|}{ US-ETF } \\
\hline & \multicolumn{18}{|c|}{ Panel A. Policy makers (PM) } \\
\hline WW & 0.3 & 0.3 & $0.24^{\star}$ & 0.31 & $0.37^{\star}$ & 0.33 & $0.31^{*}$ & 0.35 & 0.31 & $0.31^{*}$ & 0.26 & 0.31 & 0.3 & $0.26^{*}$ & 0.28 & $0.31^{*}$ & 0.31 & 0.29 \\
\hline EMU & $0.30^{*}$ & 0.3 & 0.32 & 0.28 & 0.29 & 0.3 & $0.24^{\star}$ & 0.25 & 0.3 & $0.30^{\star}$ & 0.28 & 0.33 & 0.3 & $0.28^{*}$ & $0.34^{\star}$ & 0.28 & 0.28 & 0.32 \\
\hline DE & $0.33^{*}$ & $0.32^{\star}$ & 0.3 & 0.34 & $0.32^{\star}$ & 0.32 & $0.31^{*}$ & 0.3 & 0.34 & $0.34^{*}$ & 0.3 & 0.33 & 0.32 & 0.3 & 0.34 & 0.33 & 0.31 & $0.33^{*}$ \\
\hline IT & $0.32^{*}$ & 0.34 & $0.44^{*}$ & 0.17 & 0.14 & 0.27 & 0.2 & 0.22 & 0.34 & 0.27 & 0.22 & $0.29^{*}$ & 0.32 & 0.27 & 0.34 & 0.26 & 0.24 & 0.34 \\
\hline ES & 0.2 & 0.29 & 0.24 & 0.12 & 0.12 & 0.14 & 0.08 & 0.14 & 0.27 & 0.2 & 0.2 & $0.31^{*}$ & 0.31 & 0.29 & $0.31^{\star}$ & 0.18 & 0.21 & 0.25 \\
\hline PT & 0.33 & 0.27 & $0.37^{\star}$ & $0.40^{*}$ & 0.33 & $0.37^{\star}$ & 0.33 & 0.3 & $0.40^{*}$ & 0.37 & 0.27 & 0.37 & 0.38 & 0.37 & 0.37 & 0.36 & 0.31 & 0.37 \\
\hline GR & 0.41 & 0.23 & $0.41^{*}$ & 0.14 & 0.14 & 0.23 & 0.14 & 0.05 & $0.27^{\star}$ & 0.18 & 0.14 & 0.32 & 0.32 & 0.32 & 0.32 & 0.24 & 0.18 & $0.29^{*}$ \\
\hline \multirow[t]{2}{*}{ All-PM } & 0.31 & 0.29 & $0.33^{\star}$ & 0.25 & 0.24 & 0.28 & 0.23 & 0.23 & $0.32^{*}$ & 0.28 & 0.24 & $0.33^{*}$ & 0.32 & 0.3 & $0.33^{*}$ & 0.28 & 0.26 & 0.31 \\
\hline & \multicolumn{18}{|c|}{ Panel B. Macroeconomic variables (Macro) } \\
\hline LB & 0.34 & 0.33 & 0.35 & 0.32 & $0.32^{*}$ & $0.36^{*}$ & 0.23 & $0.24^{*}$ & 0.34 & 0.33 & 0.31 & 0.32 & 0.3 & $0.33^{*}$ & 0.31 & 0.3 & $0.31^{*}$ & $0.34^{*}$ \\
\hline CIND & 0.36 & 0.34 & 0.36 & 0.31 & 0.31 & $0.31^{*}$ & 0.26 & $0.27^{\star}$ & 0.29 & 0.33 & 0.31 & $0.36^{*}$ & 0.3 & $0.29^{*}$ & 0.32 & $0.31^{*}$ & 0.3 & 0.33 \\
\hline EA & $0.28^{*}$ & 0.31 & 0.3 & 0.26 & $0.29^{\star}$ & 0.33 & 0.25 & 0.26 & $0.30^{*}$ & 0.29 & 0.27 & $0.31^{*}$ & 0.31 & 0.29 & $0.36^{*}$ & 0.28 & $0.28^{*}$ & 0.32 \\
\hline CINF & 0.31 & $0.31^{*}$ & $0.30^{*}$ & 0.28 & $0.25^{\star}$ & 0.29 & 0.27 & $0.24^{*}$ & 0.29 & 0.28 & 0.27 & $0.30^{*}$ & 0.3 & 0.27 & $0.34^{\star}$ & $0.29^{*}$ & 0.27 & 0.3 \\
\hline EM & 0.35 & 0.33 & $0.35^{*}$ & 0.36 & 0.27 & $0.39^{\star}$ & 0.27 & $0.21^{*}$ & 0.36 & 0.28 & $0.29^{\star}$ & 0.35 & 0.32 & 0.27 & 0.33 & $0.32^{*}$ & 0.27 & $0.36^{*}$ \\
\hline CB & 0.26 & 0.31 & $0.37^{*}$ & $0.30^{*}$ & 0.31 & 0.31 & 0.23 & $0.26^{*}$ & 0.29 & 0.27 & $0.26^{\star}$ & 0.32 & 0.28 & $0.30^{*}$ & 0.37 & 0.27 & 0.29 & $0.33^{*}$ \\
\hline All-Macro & 0.32 & 0.32 & $0.34^{\star}$ & 0.31 & 0.29 & 0.33 & $0.25^{*}$ & 0.25 & 0.31 & $0.30^{*}$ & 0.29 & $0.33^{*}$ & 0.3 & 0.29 & $0.34^{\star}$ & $0.30^{*}$ & 0.29 & 0.33 \\
\hline All-EE & 0.32 & 0.31 & $0.34^{*}$ & $0.28^{\star}$ & 0.27 & 0.31 & 0.24 & 0.24 & 0.32 & 0.29 & 0.27 & $0.32^{*}$ & 0.31 & 0.3 & $0.34^{\star}$ & 0.29 & 0.28 & $0.32^{*}$ \\
\hline
\end{tabular}

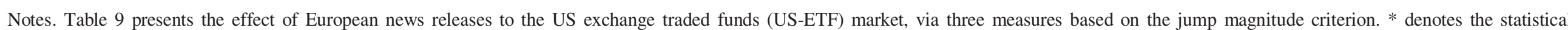
significance of rejecting the H0: equal mean between before and after, with alternative hypothesis Ha: After>Before, at a 5\% level. 
Table 10. Jump magnitude - summarized results

\begin{tabular}{|c|c|c|c|c|c|c|c|c|c|c|c|c|c|c|c|c|c|c|}
\hline & \multicolumn{3}{|c|}{ US-SSI } & \multicolumn{3}{|c|}{ US-SIF } & \multicolumn{3}{|c|}{ US-TBF } & \multicolumn{3}{|c|}{ US-SER } & \multicolumn{3}{|c|}{ US-ETF } & \multicolumn{3}{|c|}{ US-markets } \\
\hline & \multicolumn{18}{|c|}{ Panel A. Policy makers (PM) } \\
\hline WW & 0.4 & $0.39^{*}$ & 0.33 & $0.29^{*}$ & 0.33 & 0.28 & 0.35 & $0.44^{\star}$ & 0.37 & 0.33 & $0.44^{*}$ & 0.33 & 0.31 & $0.31^{\star}$ & 0.29 & $0.34^{*}$ & 0.38 & 0.32 \\
\hline EMU & 0.34 & $0.35^{*}$ & 0.32 & 0.41 & $0.47^{\star}$ & 0.23 & 0.42 & 0.47 & 0.3 & 0.41 & $0.51^{*}$ & 0.32 & 0.28 & 0.28 & 0.32 & 0.37 & 0.42 & 0.3 \\
\hline $\mathrm{DE}$ & 0.37 & $0.36^{*}$ & 0.33 & 0.43 & 0.44 & 0.29 & 0.45 & $0.50^{*}$ & 0.25 & $0.51^{*}$ & $0.48^{*}$ & 0.34 & 0.33 & 0.31 & $0.33^{*}$ & 0.42 & $0.42^{*}$ & 0.31 \\
\hline IT & 0.35 & 0.38 & 0.32 & 0.43 & $0.54^{*}$ & 0.34 & $0.47^{\star}$ & $0.51^{*}$ & 0.39 & 0.44 & $0.53^{\star}$ & 0.41 & 0.26 & 0.24 & 0.34 & $0.39^{*}$ & 0.44 & 0.36 \\
\hline ES & 0.27 & 0.28 & $0.29^{*}$ & $0.51^{*}$ & $0.58^{\star}$ & 0.22 & $0.39^{*}$ & 0.39 & 0.29 & $0.53^{*}$ & $0.65^{\star}$ & 0.33 & 0.18 & 0.21 & 0.25 & $0.38^{*}$ & 0.42 & 0.28 \\
\hline PT & $0.38^{*}$ & 0.37 & $0.36^{*}$ & 0.37 & $0.37^{\star}$ & 0.29 & 0.39 & $0.33^{*}$ & 0.17 & 0.47 & $0.40^{\star}$ & 0.27 & 0.36 & 0.31 & 0.37 & $0.39^{*}$ & 0.36 & 0.29 \\
\hline GR & $0.29^{\star}$ & 0.28 & 0.3 & 0.39 & 0.59 & 0.32 & $0.59^{\star}$ & $0.55^{\star}$ & 0.32 & 0.5 & $0.50^{\star}$ & 0.36 & 0.24 & 0.18 & $0.29^{*}$ & 0.4 & 0.42 & 0.32 \\
\hline \multirow[t]{2}{*}{ All-PM } & 0.34 & 0.34 & $0.32^{*}$ & 0.4 & $0.48^{\star}$ & 0.28 & 0.44 & 0.46 & 0.3 & 0.46 & 0.5 & 0.34 & 0.28 & $0.26^{\star}$ & 0.31 & 0.38 & $0.41^{*}$ & 0.31 \\
\hline & \multicolumn{18}{|c|}{ Panel B. Macroeconomic variables (Macro) } \\
\hline LB & 0.34 & 0.36 & 0.3 & 0.44 & $0.47^{\star}$ & 0.27 & 0.39 & $0.45^{\star}$ & 0.31 & 0.49 & $0.51^{*}$ & 0.42 & 0.3 & 0.31 & $0.34^{\star}$ & $0.39^{*}$ & 0.42 & 0.33 \\
\hline CIND & $0.36^{*}$ & 0.37 & $0.32^{*}$ & 0.43 & $0.46^{*}$ & 0.31 & $0.46^{\star}$ & 0.48 & 0.3 & 0.42 & $0.48^{*}$ & 0.38 & $0.31^{\star}$ & 0.3 & 0.33 & $0.40^{*}$ & 0.42 & 0.33 \\
\hline EA & 0.33 & 0.34 & $0.34^{*}$ & 0.4 & 0.48 & 0.21 & 0.4 & $0.48^{\star}$ & 0.31 & 0.42 & $0.52^{\star}$ & 0.36 & 0.28 & 0.28 & 0.32 & 0.37 & 0.42 & 0.31 \\
\hline CINF & $0.36^{*}$ & 0.35 & 0.34 & $0.40^{*}$ & 0.46 & 0.18 & 0.45 & $0.47^{\star}$ & 0.31 & 0.42 & $0.49^{\star}$ & 0.34 & 0.29 & 0.27 & $0.30^{*}$ & 0.38 & $0.29^{*}$ & 0.29 \\
\hline EM & 0.36 & $0.34^{\star}$ & 0.33 & 0.42 & $0.54^{\star}$ & 0.27 & 0.38 & $0.46^{\star}$ & 0.23 & 0.43 & $0.54^{\star}$ & 0.27 & 0.32 & 0.27 & 0.36 & $0.38^{*}$ & 0.43 & 0.29 \\
\hline CB & 0.32 & 0.34 & 0.32 & $0.41^{*}$ & 0.47 & 0.29 & 0.42 & $0.48^{*}$ & 0.3 & 0.36 & $0.52^{*}$ & 0.26 & 0.27 & 0.29 & 0.33 & 0.36 & $0.42^{*}$ & 0.3 \\
\hline All-Macro & 0.35 & 0.35 & 0.33 & 0.42 & 0.48 & $0.26^{*}$ & 0.42 & 0.47 & 0.29 & 0.42 & 0.51 & $0.34^{*}$ & 0.3 & $0.29^{\star}$ & 0.33 & $0.38^{*}$ & 0.42 & 0.31 \\
\hline All-EE & 0.35 & 0.35 & 0.33 & 0.41 & $0.48^{\star}$ & 0.27 & 0.43 & 0.47 & 0.3 & 0.44 & $0.51^{*}$ & 0.34 & 0.29 & 0.28 & 0.32 & 0.38 & $0.42^{*}$ & 0.31 \\
\hline
\end{tabular}

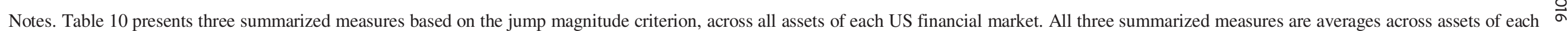
market. 
Table 11. Jump frequency criterion - US stock spot indices (US-SSI) market

\begin{tabular}{|c|c|c|c|c|c|c|c|c|c|c|c|c|c|c|c|c|c|c|c|c|c|c|c|c|}
\hline & \multicolumn{3}{|c|}{ INDU } & \multicolumn{3}{|c|}{ NDX } & \multicolumn{3}{|c|}{ INX } & \multicolumn{3}{|c|}{ COMPX } & \multicolumn{3}{|c|}{ RUT } & \multicolumn{3}{|c|}{ OEX } & \multicolumn{3}{|c|}{ IDX } & \multicolumn{3}{|c|}{ US-SSI } \\
\hline & \multicolumn{24}{|c|}{ Panel A. Policy makers (PM) } \\
\hline WW & $0.54^{*}$ & 0.48 & $0.61^{*}$ & $0.52^{\star}$ & 0.35 & $0.54^{\star}$ & $0.57^{\star}$ & 0.48 & $0.52^{*}$ & $0.57^{\star}$ & 0.41 & $0.57^{\star}$ & $0.56^{*}$ & 0.44 & $0.57^{\star}$ & $0.57^{\star}$ & 0.44 & $0.56^{\star}$ & 0.61 & 0.48 & 0.57 & $0.56^{\star}$ & 0.44 & $0.56^{*}$ \\
\hline EMU & 0.58 & 0.52 & $0.58^{\star}$ & $0.57^{\star}$ & $0.52^{*}$ & $0.57^{\star}$ & $0.63^{*}$ & $0.57^{\star}$ & $0.63^{*}$ & $0.63^{\star}$ & $0.57^{\star}$ & $0.63^{*}$ & $0.73^{*}$ & $0.66^{\star}$ & $0.73^{*}$ & $0.59^{\star}$ & $0.53^{\star}$ & 0.59 & $0.65^{*}$ & $0.58^{*}$ & $0.65^{*}$ & $0.63^{*}$ & $0.56^{*}$ & $0.63^{*}$ \\
\hline $\mathrm{DE}$ & $0.59^{*}$ & 0.45 & $0.59^{*}$ & $0.55^{*}$ & 0.43 & 0.55 & $0.65^{*}$ & 0.52 & 0.65 & 0.62 & 0.49 & 0.62 & $0.71^{*}$ & 0.56 & $0.71^{*}$ & $0.62^{\star}$ & 0.49 & $0.62^{*}$ & $0.65^{*}$ & 0.51 & $0.65^{*}$ & $0.63^{*}$ & 0.49 & $0.63^{*}$ \\
\hline IT & 0.47 & $0.37^{\star}$ & 0.47 & 0.56 & $0.42^{*}$ & 0.56 & 0.63 & 0.49 & 0.63 & $0.58^{\star}$ & 0.47 & $0.58^{\star}$ & $0.63^{*}$ & 0.51 & $0.63^{*}$ & 0.61 & 0.44 & $0.61^{*}$ & $0.68^{\star}$ & $0.53^{*}$ & $0.68^{\star}$ & $0.59^{\star}$ & 0.46 & $0.59^{*}$ \\
\hline ES & 0.49 & 0.49 & 0.49 & $0.59^{*}$ & $0.51^{\star}$ & $0.55^{*}$ & $0.53^{*}$ & 0.45 & $0.53^{*}$ & $0.63^{*}$ & $0.53^{*}$ & $0.63^{*}$ & 0.63 & $0.55^{\star}$ & $0.63^{*}$ & 0.49 & 0.47 & 0.49 & $0.59^{*}$ & 0.49 & $0.59^{*}$ & $0.56^{\star}$ & 0.5 & 0.56 \\
\hline PT & 0.47 & 0.4 & 0.47 & $0.57^{\star}$ & $0.47^{\star}$ & $0.57^{\star}$ & 0.53 & 0.48 & $0.53^{*}$ & 0.47 & 0.47 & 0.47 & $0.67^{\star}$ & 0.53 & $0.67^{\star}$ & $0.53^{\star}$ & 0.43 & 0.53 & $0.57^{*}$ & $0.57^{\star}$ & $0.57^{\star}$ & $0.54^{*}$ & $0.48^{\star}$ & $0.54^{*}$ \\
\hline GR & 0.55 & $0.55^{\star}$ & 0.45 & 0.45 & $0.50^{\star}$ & 0.45 & $0.55^{\star}$ & $0.59^{\star}$ & 0.09 & 0.45 & 0.5 & 0.45 & 0.55 & $0.59^{*}$ & 0.55 & $0.59^{\star}$ & $0.59^{*}$ & 0.55 & $0.55^{\star}$ & $0.55^{*}$ & 0.5 & 0.53 & $0.55^{*}$ & 0.43 \\
\hline \multirow[t]{2}{*}{ All-PM } & $0.53^{*}$ & 0.47 & $0.52^{*}$ & $0.54^{*}$ & 0.46 & $0.54^{*}$ & $0.58^{*}$ & 0.51 & 0.51 & $0.56^{*}$ & 0.49 & $0.56^{\star}$ & $0.64^{*}$ & $0.55^{*}$ & 0.64 & $0.57^{\star}$ & 0.48 & $0.56^{*}$ & $0.61^{*}$ & $0.53^{*}$ & $0.60^{*}$ & $0.58^{\star}$ & 0.5 & $0.56^{\star}$ \\
\hline & \multicolumn{24}{|c|}{ Panel B. Macroeconomic variables (Macro) } \\
\hline LB & 0.55 & 0.43 & $0.55^{*}$ & $0.57^{\star}$ & 0.43 & $0.57^{\star}$ & $0.66^{*}$ & $0.52^{*}$ & $0.66^{*}$ & $0.63^{*}$ & 0.48 & $0.62^{*}$ & $0.74^{*}$ & $0.57^{*}$ & $0.74^{*}$ & $0.60^{\star}$ & 0.45 & $0.60^{\star}$ & $0.65^{*}$ & $0.50^{*}$ & $0.65^{\star}$ & 0.63 & 0.48 & 0.63 \\
\hline CIND & $0.51^{*}$ & 0.39 & 0.51 & 0.58 & 0.44 & $0.58^{*}$ & 0.64 & $0.51^{*}$ & $0.63^{*}$ & 0.64 & 0.51 & 0.64 & $0.76^{*}$ & $0.58^{*}$ & $0.76^{*}$ & $0.60^{\star}$ & 0.46 & $0.59^{*}$ & $0.70^{*}$ & $0.53^{*}$ & $0.70^{*}$ & $0.63^{*}$ & $0.49^{*}$ & $0.63^{*}$ \\
\hline EA & $0.57^{*}$ & 0.44 & 0.57 & $0.56^{*}$ & 0.41 & 0.56 & $0.60^{*}$ & $0.46^{*}$ & $0.60^{*}$ & $0.61^{*}$ & $0.46^{*}$ & $0.61^{*}$ & 0.73 & $0.55^{*}$ & $0.73^{*}$ & $0.59^{*}$ & 0.45 & 0.59 & $0.66^{*}$ & $0.51^{*}$ & $0.66^{*}$ & $0.62^{*}$ & 0.47 & 0.62 \\
\hline CINF & $0.57^{\star}$ & 0.42 & 0.57 & $0.56^{*}$ & 0.41 & 0.56 & $0.63^{*}$ & $0.47^{\star}$ & $0.63^{*}$ & $0.61^{*}$ & 0.45 & $0.61^{*}$ & $0.71^{*}$ & $0.54^{\star}$ & $0.71^{*}$ & $0.59^{\star}$ & $0.43^{\star}$ & $0.59^{\star}$ & $0.65^{\star}$ & $0.47^{\star}$ & 0.65 & $0.62^{*}$ & $0.46^{\star}$ & $0.62^{*}$ \\
\hline EM & $0.61^{*}$ & 0.44 & $0.61^{*}$ & $0.57^{\star}$ & $0.40^{\star}$ & $0.55^{*}$ & $0.63^{*}$ & 0.45 & $0.63^{*}$ & $0.63^{*}$ & 0.51 & 0.61 & $0.72^{\star}$ & $0.50^{*}$ & $0.72^{*}$ & $0.61^{*}$ & 0.43 & $0.61^{*}$ & $0.63^{*}$ & 0.48 & $0.63^{*}$ & $0.63^{*}$ & 0.46 & 0.62 \\
\hline $\mathrm{CB}$ & 0.57 & 0.45 & $0.57^{\star}$ & 0.54 & 0.43 & $0.54^{\star}$ & $0.63^{*}$ & 0.5 & $0.63^{*}$ & $0.62^{*}$ & 0.5 & $0.62^{*}$ & $0.70^{*}$ & $0.54^{\star}$ & $0.70^{*}$ & $0.59^{\star}$ & 0.46 & $0.59^{\star}$ & $0.64^{*}$ & 0.5 & $0.64^{*}$ & $0.61^{*}$ & 0.48 & $0.61^{*}$ \\
\hline $\begin{array}{l}\text { All- } \\
\text { Macro }\end{array}$ & $0.56^{*}$ & 0.43 & $0.56^{*}$ & $0.56^{*}$ & 0.42 & $0.56^{\star}$ & $0.63^{*}$ & 0.49 & $0.63^{*}$ & $0.62^{*}$ & 0.49 & 0.62 & $0.73^{*}$ & $0.55^{\star}$ & $0.73^{\star}$ & $0.60^{\star}$ & 0.45 & $0.60^{*}$ & $0.66^{*}$ & 0.5 & $0.66^{*}$ & $0.62^{*}$ & 0.47 & $0.62^{*}$ \\
\hline All-EE & $0.55^{*}$ & 0.45 & $0.54^{\star}$ & $0.56^{*}$ & $0.44^{\star}$ & $0.55^{\star}$ & 0.61 & 0.5 & 0.57 & $0.59^{\star}$ & 0.49 & 0.59 & $0.69^{*}$ & $0.55^{\star}$ & $0.69^{\star}$ & $0.59^{\star}$ & 0.47 & $0.58^{\star}$ & $0.64^{\star}$ & $0.52^{\star}$ & $0.63^{\star}$ & $0.60^{*}$ & 0.49 & $0.59^{*}$ \\
\hline
\end{tabular}

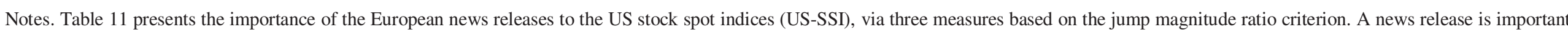

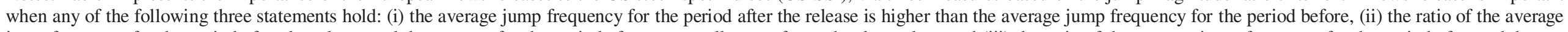

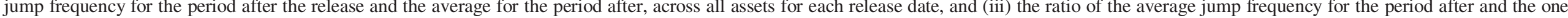

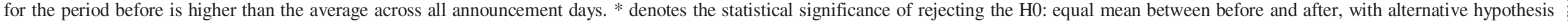

Ha: After>Before, at a 5\% level. 
Table 12. Jump frequency criterion - US stock index futures (US-SIF), US Treasury bond futures (US-TBF) and US spot exchange rates (US-SER) markets

\begin{tabular}{|c|c|c|c|c|c|c|c|c|c|c|c|c|}
\hline & \multicolumn{6}{|c|}{ US-SIF } & \multirow{2}{*}{\multicolumn{3}{|c|}{$\frac{\text { US-TBF }}{\text { TYX }}$}} & \multirow{2}{*}{\multicolumn{3}{|c|}{$\begin{array}{c}\text { US-SER } \\
\text { DXY }\end{array}$}} \\
\hline & \multicolumn{3}{|c|}{ ES } & \multicolumn{3}{|c|}{$\mathrm{NQ}$} & & & & & & \\
\hline & \multicolumn{12}{|c|}{ Panel A. Policy makers (PM) } \\
\hline WW & $0.89^{*}$ & $0.69^{\star}$ & $0.61^{*}$ & $0.91^{*}$ & 0.69 & $0.89^{*}$ & $0.57^{\star}$ & $0.54^{*}$ & $0.56^{*}$ & $0.96^{*}$ & $0.72^{*}$ & 0.57 \\
\hline EMU & $0.92^{*}$ & $0.85^{*}$ & $0.92^{*}$ & $0.76^{*}$ & $0.69^{*}$ & $0.76^{*}$ & $0.75^{\star}$ & $0.68^{\star}$ & $0.75^{*}$ & $0.97^{\star}$ & $0.92^{*}$ & 0.98 \\
\hline $\mathrm{DE}$ & $0.92^{*}$ & $0.70^{*}$ & 0.62 & $0.78^{\star}$ & $0.60^{*}$ & $0.78^{\star}$ & $0.78^{\star}$ & $0.61^{*}$ & 0.78 & $0.98^{\star}$ & 0.74 & $0.99^{\prime}$ \\
\hline IT & $0.90^{*}$ & $0.71^{*}$ & $0.90^{*}$ & $0.75^{\star}$ & 0.66 & $0.75^{\star}$ & $0.86^{*}$ & $0.71^{*}$ & $0.85^{\star}$ & $0.97^{*}$ & 0.71 & $0.97^{*}$ \\
\hline ES & $0.86^{\star}$ & $0.65^{\star}$ & $0.86^{\star}$ & $0.80^{\star}$ & 0.63 & $0.80^{*}$ & $0.76^{*}$ & 0.65 & $0.76^{*}$ & $0.96^{*}$ & $0.69^{*}$ & 0.96 \\
\hline PT & $0.80^{*}$ & $0.67^{*}$ & $0.80^{*}$ & $0.70^{*}$ & $0.57^{\star}$ & $0.70^{*}$ & $0.77^{\star}$ & $0.67^{*}$ & $0.77^{*}$ & $0.90^{*}$ & $0.77^{\star}$ & $0.90^{\prime}$ \\
\hline GR & $0.86^{\star}$ & 0.68 & $0.05^{\star}$ & $0.73^{\star}$ & $0.73^{\star}$ & 0.18 & $0.77^{\star}$ & $0.64^{*}$ & 0.1 & $0.95^{\star}$ & $0.73^{*}$ & 0.1 \\
\hline \multirow[t]{2}{*}{ All-PM } & $0.89^{*}$ & $0.71^{*}$ & 0.68 & $0.78^{\star}$ & $0.65^{*}$ & $0.69^{\star}$ & $0.75^{\star}$ & $0.64^{*}$ & $0.65^{\star}$ & $0.96^{*}$ & $0.75^{*}$ & 0.74 \\
\hline & \multicolumn{12}{|c|}{ Panel B. Macroeconomic variables (Macro) } \\
\hline LB & $0.96^{\star}$ & 0.7 & $0.96^{*}$ & $0.74^{*}$ & 0.55 & $0.74^{\star}$ & $0.78^{\star}$ & 0.57 & $0.76^{*}$ & $0.98^{\star}$ & 0.72 & $0.99^{\circ}$ \\
\hline CIND & $0.95^{*}$ & 0.67 & $0.95^{\star}$ & $0.78^{*}$ & 0.55 & $0.78^{\star}$ & $0.80^{*}$ & 0.59 & $0.80^{*}$ & $0.99^{*}$ & $0.69^{*}$ & $0.99^{\prime}$ \\
\hline EA & $0.92^{*}$ & 0.69 & $0.92^{*}$ & $0.78^{*}$ & $0.60^{*}$ & $0.78^{\star}$ & $0.77^{\star}$ & $0.61^{*}$ & $0.77^{\star}$ & $0.99^{*}$ & $0.74^{*}$ & $0.99^{\circ}$ \\
\hline CINF & $0.95^{\star}$ & $0.69^{*}$ & $0.95^{*}$ & $0.80^{*}$ & 0.61 & 0.79 & $0.75^{\star}$ & $0.57^{*}$ & $0.75^{\star}$ & $0.98^{*}$ & $0.71^{*}$ & $0.99^{\prime}$ \\
\hline EM & $0.89^{*}$ & 0.64 & $0.89^{*}$ & $0.71^{*}$ & 0.49 & $0.71^{*}$ & $0.84^{*}$ & $0.61^{*}$ & $0.84^{*}$ & $0.99^{*}$ & 0.66 & $0.99^{\prime}$ \\
\hline $\mathrm{CB}$ & $0.86^{\star}$ & $0.65^{*}$ & $0.86^{*}$ & $0.71^{*}$ & 0.54 & $0.71^{*}$ & $0.67^{\star}$ & $0.54^{*}$ & $0.67^{\star}$ & $0.99^{*}$ & 0.75 & $0.99^{\prime}$ \\
\hline All-Macro & $0.92^{\star}$ & 0.67 & $0.92^{*}$ & 0.75 & 0.56 & $0.75^{\star}$ & $0.77^{\star}$ & $0.58^{*}$ & $0.77^{\star}$ & $0.99^{*}$ & 0.71 & $0.99^{\prime}$ \\
\hline All-EE & $0.91^{*}$ & 0.69 & $0.80^{*}$ & $0.77^{\star}$ & $0.61^{*}$ & $0.72^{*}$ & $0.76^{\star}$ & $0.61^{*}$ & $0.71^{*}$ & $0.98^{\star}$ & 0.73 & 0.87 \\
\hline
\end{tabular}

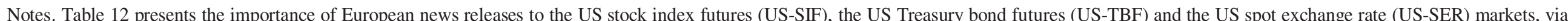

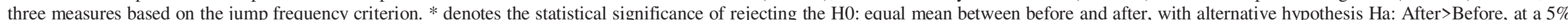
level. 
Table 13. Jump frequency criterion - US exchange traded funds (US-ETF) market

\begin{tabular}{|c|c|c|c|c|c|c|c|c|c|c|c|c|c|c|c|c|c|c|}
\hline & \multicolumn{3}{|c|}{$\mathrm{QQQ}$} & \multicolumn{3}{|c|}{ SPY } & \multicolumn{3}{|c|}{ DIA } & \multicolumn{3}{|c|}{ MDY } & \multicolumn{3}{|c|}{ IWM } & \multicolumn{3}{|c|}{ US-ETF } \\
\hline & \multicolumn{18}{|c|}{ Panel A. Policy makers (PM) } \\
\hline WW & $0.50^{*}$ & 0.39 & $0.91^{*}$ & $0.54^{*}$ & 0.43 & 0.5 & $0.54^{*}$ & 0.43 & $0.54^{*}$ & $0.56^{*}$ & 0.41 & 0.54 & 0.56 & 0.43 & $0.56^{*}$ & $0.54^{*}$ & $0.42^{*}$ & $0.61^{*}$ \\
\hline EMU & $0.56^{*}$ & 0.5 & $0.56^{*}$ & $0.53^{*}$ & 0.48 & 0.53 & $0.55^{*}$ & 0.49 & $0.55^{*}$ & $0.57^{*}$ & $0.51^{*}$ & $0.57^{*}$ & $0.58^{*}$ & $0.52^{*}$ & $0.58^{*}$ & $0.56^{*}$ & $0.50^{*}$ & $0.56^{*}$ \\
\hline $\mathrm{DE}$ & $0.59^{*}$ & 0.44 & $0.59^{*}$ & $0.53^{*}$ & 0.4 & 0.53 & $0.56^{*}$ & 0.43 & $0.56^{*}$ & $0.59^{*}$ & $0.47^{\star}$ & $0.59^{*}$ & $0.57^{\star}$ & 0.43 & $0.57^{*}$ & $0.57^{*}$ & 0.43 & $0.57^{*}$ \\
\hline IT & $0.53^{*}$ & 0.46 & 0.53 & $0.39^{*}$ & 0.31 & 0.39 & $0.47^{*}$ & $0.41^{*}$ & $0.47^{*}$ & $0.49^{\star}$ & 0.37 & 0.49 & 0.49 & 0.39 & 0.49 & 0.47 & $0.39^{*}$ & 0.47 \\
\hline ES & $0.53^{\star}$ & $0.49^{*}$ & $0.49^{*}$ & 0.43 & 0.37 & 0.43 & 0.45 & 0.41 & 0.45 & $0.51^{*}$ & $0.39^{*}$ & $0.51^{*}$ & $0.53^{\star}$ & 0.39 & 0.49 & 0.49 & 0.41 & 0.47 \\
\hline PT & 5 & 0.43 & $0.50^{\star}$ & 0.4 & $0.37^{*}$ & 0.4 & 0.5 & 0.43 & 0.5 & $0.57^{\star}$ & 0.47 & $0.53^{*}$ & $0.57^{\star}$ & $0.50^{\star}$ & $0.57^{\star}$ & $0.51^{*}$ & 0.44 & 0.5 \\
\hline GR & 0.41 & 0.41 & 0.41 & $0.45^{\star}$ & $0.50^{*}$ & 0.45 & 0.36 & 0.32 & 0.36 & $0.55^{\star}$ & 0.45 & $0.55^{\star}$ & $0.55^{\star}$ & $0.59^{\star}$ & $0.55^{\star}$ & 0.46 & 0.45 & 0.46 \\
\hline \multirow[t]{2}{*}{ All-PM } & $0.52^{\star}$ & 0.45 & $0.57^{\star}$ & 0.47 & 0.41 & 0.46 & 0.49 & $0.42^{\star}$ & 0.49 & $0.55^{*}$ & 0.44 & $0.54^{*}$ & $0.55^{*}$ & 0.46 & $0.54^{*}$ & $0.51^{\star}$ & 0.43 & 0.52 \\
\hline & \multicolumn{18}{|c|}{ Panel B. Macroeconomic variables (Macro) } \\
\hline LB & 0.48 & 0.42 & $0.56^{*}$ & $0.54^{*}$ & 0.35 & 0.48 & $0.57^{*}$ & 0.39 & $0.54^{*}$ & $0.53^{*}$ & $0.43^{*}$ & $0.57^{*}$ & $0.76^{*}$ & 0.41 & $0.53^{*}$ & $0.58^{*}$ & 0.40 & $0.54^{*}$ \\
\hline CIND & $0.58^{\star}$ & 0.43 & $0.57^{*}$ & $0.55^{\star}$ & 0.40 & $0.54^{*}$ & $0.54^{*}$ & 0.39 & $0.54^{*}$ & $0.61^{*}$ & 0.44 & $0.61^{*}$ & $0.52^{*}$ & 0.39 & $0.51^{*}$ & $0.56^{*}$ & $0.41^{*}$ & $0.55^{*}$ \\
\hline EA & $0.57^{\star}$ & 0.44 & $0.57^{\star}$ & $0.54^{\star}$ & $0.41^{*}$ & $0.54^{*}$ & $0.55^{\star}$ & 0.43 & 0.55 & 0.58 & 0.44 & 0.58 & $0.55^{\star}$ & $0.44^{*}$ & $0.55^{*}$ & $0.56^{\star}$ & 0.43 & 0.56 \\
\hline CINF & $0.58^{\star}$ & 0.44 & $0.58^{\star}$ & 0.53 & 0.39 & $0.53^{\star}$ & $0.51^{*}$ & 0.39 & $0.51^{*}$ & $0.58^{*}$ & 0.45 & $0.58^{*}$ & $0.58^{\star}$ & 0.45 & $0.58^{*}$ & $0.56^{*}$ & 0.42 & $0.56^{\star}$ \\
\hline EM & $0.58^{\star}$ & 0.43 & $0.57^{\star}$ & $0.51^{*}$ & 0.39 & $0.51^{*}$ & 0.49 & 0.35 & 0.49 & $0.57^{*}$ & 0.40 & $0.57^{*}$ & $0.58^{*}$ & 0.45 & $0.58^{*}$ & $0.55^{\star}$ & 0.40 & $0.54^{*}$ \\
\hline $\mathrm{CB}$ & $0.53^{\star}$ & 0.4 & $0.53^{*}$ & $0.52^{*}$ & 0.39 & $0.52^{*}$ & $0.56^{*}$ & 0.42 & $0.56^{*}$ & $0.53^{*}$ & $0.43^{\star}$ & $0.53^{*}$ & $0.53^{*}$ & $0.43^{\star}$ & $0.53^{*}$ & $0.53^{\star}$ & 0.41 & $0.53^{*}$ \\
\hline All-Macro & $0.55^{\star}$ & 0.43 & $0.56^{*}$ & $0.53^{*}$ & 0.39 & 0.52 & $0.54^{*}$ & 0.40 & 0.53 & $0.57^{\star}$ & 0.43 & $0.57^{\star}$ & $0.59^{*}$ & 0.43 & $0.55^{*}$ & $0.56^{\star}$ & 0.48 & 0.55 \\
\hline All-EE & $0.54^{*}$ & 0.44 & $0.57^{\star}$ & 0.50 & 0.40 & 0.49 & 0.52 & 0.41 & 0.51 & $0.56^{*}$ & 0.44 & $0.55^{\star}$ & $0.57^{\star}$ & 0.45 & $0.55^{*}$ & $0.54^{\star}$ & $0.46^{*}$ & $0.54^{*}$ \\
\hline
\end{tabular}

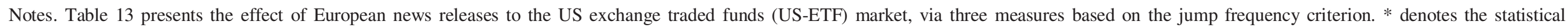
significance of rejecting the H0: equal mean between before and after, with alternative hypothesis Ha: After>Before, at a 5\% level. 
Table 14. Jump frequency criterion - Summarized results

\begin{tabular}{|c|c|c|c|c|c|c|c|c|c|c|c|c|c|c|c|c|c|c|}
\hline & \multicolumn{3}{|c|}{ US-SSI } & \multicolumn{3}{|c|}{ US-SIF } & \multicolumn{3}{|c|}{ US-TBF } & \multicolumn{3}{|c|}{ US-SER } & \multicolumn{3}{|c|}{ US-ETF } & \multicolumn{3}{|c|}{ US-markets } \\
\hline & \multicolumn{18}{|c|}{ Panel A. Policy makers (PM) } \\
\hline WW & $0.56^{\star}$ & 0.44 & $0.56^{\star}$ & $0.90^{*}$ & $0.69^{\star}$ & $0.75^{\star}$ & $0.57^{\star}$ & $0.54^{\star}$ & $0.56^{*}$ & $0.96^{*}$ & $0.72^{*}$ & 0.57 & $0.54^{*}$ & 0.42 & $0.61^{*}$ & $0.71^{*}$ & $0.56^{\star}$ & $0.61^{*}$ \\
\hline EMU & $0.63^{*}$ & $0.56^{\star}$ & $0.63^{*}$ & $0.84^{*}$ & $0.71^{*}$ & $0.84^{\star}$ & $0.75^{\star}$ & $0.68^{\star}$ & $0.75^{\star}$ & $0.97^{\star}$ & $0.92^{*}$ & $0.98^{\star}$ & $0.56^{*}$ & $0.50^{*}$ & $0.56^{*}$ & $0.75^{\star}$ & $0.67^{\star}$ & 0.42 \\
\hline $\mathrm{DE}$ & $0.63^{\star}$ & 0.49 & 0.63 & $0.85^{\star}$ & $0.65^{*}$ & $0.70^{\star}$ & $0.78^{\star}$ & 0.61 & $0.78^{\star}$ & $0.98^{*}$ & 0.74 & $0.99^{*}$ & 0.57 & 0.43 & 0.57 & $0.76^{\star}$ & 0.58 & $0.73^{*}$ \\
\hline IT & $0.59^{\star}$ & 0.46 & $0.59^{\star}$ & $0.83^{*}$ & $0.69^{*}$ & $0.83^{\star}$ & $0.86^{\star}$ & $0.71^{\star}$ & $0.85^{\star}$ & $0.97^{\star}$ & 0.71 & $0.97^{\star}$ & 0.47 & 0.39 & 0.47 & $0.74^{\star}$ & $0.59^{\star}$ & $0.74^{*}$ \\
\hline ES & $0.56^{\star}$ & 0.5 & 0.56 & $0.83^{*}$ & 0.64 & $0.83^{*}$ & $0.76^{\star}$ & $0.65^{\star}$ & $0.76^{*}$ & $0.96^{\star}$ & 0.69 & $0.96^{*}$ & 0.49 & 0.41 & 0.47 & $0.72^{*}$ & $0.58^{*}$ & $0.72^{*}$ \\
\hline PT & 0.54 & 0.48 & 0.54 & $0.75^{\star}$ & $0.62^{*}$ & $0.75^{\star}$ & $0.77^{\star}$ & $0.67^{\star}$ & $0.77^{\star}$ & $0.90^{\star}$ & $0.77^{\star}$ & $0.90^{*}$ & 0.51 & 0.44 & 0.5 & $0.69^{*}$ & $0.60^{\star}$ & $0.69^{*}$ \\
\hline GR & 0.53 & 0.55 & 0.43 & $0.80^{*}$ & $0.71^{*}$ & 0.12 & $0.77^{\star}$ & $0.64^{*}$ & 0.1 & $0.95^{*}$ & $0.73^{*}$ & 0.1 & 0.46 & 0.45 & 0.46 & $0.70^{*}$ & $0.62^{*}$ & 0.24 \\
\hline \multirow[t]{2}{*}{ All-PM } & 0.58 & 0.5 & 0.56 & $0.84^{\star}$ & $0.68^{*}$ & $0.69^{*}$ & $0.75^{\star}$ & $0.64^{*}$ & $0.65^{*}$ & $0.96^{*}$ & $0.75^{\star}$ & $0.74^{*}$ & 0.51 & 0.43 & 0.52 & $0.72^{*}$ & 0.6 & 0.6 \\
\hline & \multicolumn{18}{|c|}{ Panel B. Macroeconomic variables (Macro) } \\
\hline LB & $0.63^{\star}$ & 0.48 & $0.63^{*}$ & $0.85^{\star}$ & $0.63^{*}$ & $0.85^{\star}$ & $0.78^{\star}$ & 0.57 & $0.76^{*}$ & $0.98^{*}$ & $0.72^{*}$ & $0.99^{\star}$ & $0.58^{\star}$ & 0.4 & 0.54 & $0.76^{*}$ & $0.56^{\star}$ & $0.75^{*}$ \\
\hline CIND & $0.63^{*}$ & 0.49 & $0.63^{*}$ & $0.87^{\star}$ & $0.61^{*}$ & $0.87^{\star}$ & $0.80^{*}$ & 0.59 & $0.80^{*}$ & $0.99^{*}$ & 0.69 & $0.99^{\star}$ & 0.56 & 0.41 & 0.55 & $0.77^{\star}$ & 0.56 & $0.77^{\star}$ \\
\hline EA & $0.62^{*}$ & 0.47 & $0.62^{*}$ & $0.85^{*}$ & 0.65 & $0.85^{*}$ & $0.77^{\star}$ & $0.61^{*}$ & $0.77^{\star}$ & $0.99^{*}$ & $0.74^{*}$ & $0.99^{*}$ & $0.56^{*}$ & 0.43 & 0.56 & $0.76^{*}$ & $0.58^{*}$ & $0.76^{\star}$ \\
\hline CINF & $0.62^{\star}$ & 0.46 & $0.62^{\star}$ & $0.88^{*}$ & $0.65^{\star}$ & $0.87^{\star}$ & $0.75^{\star}$ & $0.57^{\star}$ & $0.75^{\star}$ & $0.98^{\star}$ & $0.71^{\star}$ & $0.99^{\star}$ & 0.56 & 0.42 & 0.56 & $0.76^{\star}$ & $0.56^{\star}$ & $0.76^{*}$ \\
\hline EM & $0.63^{*}$ & 0.46 & $0.62^{*}$ & $0.80^{*}$ & 0.57 & $0.80^{*}$ & $0.84^{*}$ & 0.6 & $0.84^{*}$ & $0.99^{*}$ & $0.66^{*}$ & $0.99^{\star}$ & 0.55 & $0.40^{*}$ & 0.54 & $0.76^{*}$ & $0.54^{\star}$ & 0.76 \\
\hline $\mathrm{CB}$ & 0.61 & $0.48^{\star}$ & 0.61 & $0.79^{*}$ & 0.6 & $0.79^{\star}$ & $0.67^{\star}$ & 0.54 & $0.67^{\star}$ & $0.99^{*}$ & $0.75^{\star}$ & $0.99^{\star}$ & 0.53 & 0.41 & $0.53^{\star}$ & $0.72^{*}$ & 0.56 & $0.72^{*}$ \\
\hline All-Macro & $0.62^{\star}$ & 0.47 & $0.62^{*}$ & $0.84^{*}$ & 0.62 & $0.84^{\star}$ & $0.77^{\star}$ & 0.58 & $0.77^{\star}$ & $0.99^{\star}$ & $0.71^{\star}$ & $0.99^{\star}$ & 0.56 & 0.48 & 0.55 & $0.76^{*}$ & 0.56 & $0.75^{\star}$ \\
\hline All-EE & $0.60^{\star}$ & 0.49 & $0.59^{\star}$ & $0.84^{*}$ & $0.65^{*}$ & $0.76^{*}$ & $0.76^{\star}$ & $0.61^{*}$ & $0.71^{*}$ & $0.98^{*}$ & $0.73^{*}$ & $0.87^{\star}$ & 0.54 & 0.46 & 0.54 & $0.74^{*}$ & $0.58^{\star}$ & $0.68^{\star}$ \\
\hline
\end{tabular}

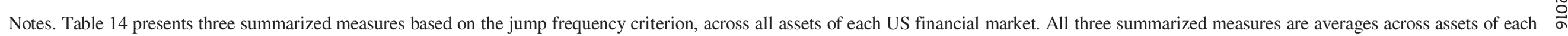
market. 
Table 15. Summarized results - US financial markets

\begin{tabular}{|c|c|c|c|c|c|c|}
\hline & US-SSI & US-SIF & US-TBF & US-SER & US-ETF & US-markets \\
\hline & \multicolumn{6}{|c|}{ Panel A. Policy makers (PM) } \\
\hline RRSR & WW & EMU & DE & EMU & DE & EMU \\
\hline RAJM & WW & ES & GR & ES & PT & ES \\
\hline \multirow[t]{3}{*}{ RJF } & EMU & EMU & IT & $\mathrm{DE}$ & $\mathrm{DE}$ & $\mathrm{DE}$ \\
\hline & WW & EMU & $\mathrm{DE}$ & EMU & $\mathrm{DE}$ & EMU/DE \\
\hline & \multicolumn{6}{|c|}{ Panel B. Macroeconomic variables (Macro) } \\
\hline RRSR & CIND & $\mathrm{CB}$ & $\mathrm{CB}$ & EM & CIND & $\mathrm{CB}$ \\
\hline RAJM & CIND & EM & CIND & LB & EM & $\mathrm{CB}$ \\
\hline \multirow[t]{2}{*}{ RJF } & CIND & LB & CINF & $\mathrm{CB}$ & EA & CIND \\
\hline & CIND & $\mathrm{CB}$ & $\mathrm{CB}$ & LB & CIND & $\mathrm{CB}$ \\
\hline
\end{tabular}

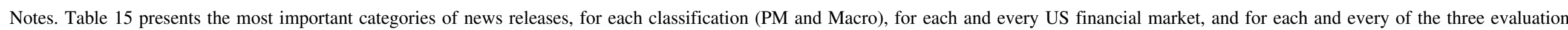
criteria. 